\title{
Management of Low-Level Radioactive Wastes Around the World
}
L. T. Lakey
K. M. Harmon
P. Colombo

\section{April 1985}

Prepared for the U.S. Department of Energy under Contract DE-AC06-76RLO 1830

Pacific Northwest Laboratory Operated for the U.S. Department of Energy by Battelle Memorial Institute 


\title{
DISCLAIMER
}

This report was prepared as an account of work sponsored by an agency of the United States Government. Neither the United States Government nor any agency thereof, nor any of their employees, makes any warranty, express or implied, or assumes any legal liability or responsibility for the accuracy, completeness, or usefulness of any information, apparatus, product, or process disclosed, or represents that its use would not infringe privately owned rights. Reference herein to any specific commercial product, process, or service by trade name, trademark, manufacturer, or otherwise, does not necessarily constitute or imply its endorsement, recommendation, or favoring by the United States Government or any agency thereof. The views and opinions of authors expressed herein do not necessarily state or reflect those of the United States Government or any agency thereof.

\author{
PACIFIC NORTHWEST LABORATORY \\ operated by \\ BATTELLE \\ for the \\ UNITED STATES DEPARTMENT OF ENERGY \\ under Contract DE-AC06-76RLO 1830
}

\begin{tabular}{|c|c|}
\hline \multirow{2}{*}{\multicolumn{2}{|c|}{ Printed in the United States of America }} \\
\hline & \\
\hline \multicolumn{2}{|c|}{ Available from } \\
\hline \multicolumn{2}{|c|}{ National Technical Information Service } \\
\hline \multicolumn{2}{|c|}{ United States Depariment of Commerce } \\
\hline \multicolumn{2}{|c|}{ Springfield, Virginia 22161} \\
\hline \multirow{2}{*}{\multicolumn{2}{|c|}{$\begin{array}{l}\text { NTIS Price Codes } \\
\text { Microfiche A01 }\end{array}$}} \\
\hline & \\
\hline \multicolumn{2}{|c|}{ Printed Copy } \\
\hline & Price \\
\hline Pages & Codes \\
\hline $001-025$ & $\mathrm{~A} 02$ \\
\hline $026-050$ & $A 03$ \\
\hline $051-075$ & $\mathrm{~A} 04$ \\
\hline $076-100$ & A05 \\
\hline $101-125$ & A06 \\
\hline $126-150$ & A07 \\
\hline $151-175$ & $A 00$ \\
\hline $176-200$ & $A 09$ \\
\hline $201-225$ & $A 010$ \\
\hline $226-250$ & A011 \\
\hline $251-275$ & $\mathrm{~A} 012$ \\
\hline $276-300$ & $A 013$ \\
\hline
\end{tabular}


MANAGEMENT OF LOW-LEVEL RADIOACTIVE WASTES AROUND THE WORLD
L. T. Lakey
K. M. Harmon
P. Col ombo (a)

Apri1 1985

Prepared for the U.S. Department of Energy under Contract DE-AC06-76RL0 1830

Pacific Northwest Laboratory Richland, Washington 99352

(a) Brookhaven National Laboratory 
1 


\section{SUMMARY}

Low-level radioactive wastes are produced worldwide from nuclear power programs, weapon material activities and institutional/industrial uses of radionuclides. The latter uses are spread worldwide in such activities as medical care, research, instrumentation, and testing. Nuclear power and weapon material programs are confined largely to the more highly developed countries. The quantities and sources of low-level wastes produced in a country are therefore very dependent upon the country's economy.

Though treatment of low-level wastes from fuel cycle activities and institutional/industrial uses of radionuclides is generally the responsibility of the generator, disposal is invariabily the responsibility of the government, as is regulation. Costs of the low-level waste management, including those of hoth treatment and disposal, are borne by the producer.

While low-level radioactive wastes have a wide spectrum of chemical and physical characteristics, this class of radioactive waste is generally identified as that being contaminated with radionuclides having half-lives shorter than 30 years. The upper radioactivity limit is generally given in terms of the long-lived radionuclide content, e.g., $100 \mathrm{nCi} / \mathrm{g}$ in the U.S.A. The lower radioactivity limit is the deminimus, or throwaway value, which has been set in a few countries and is being studied in many more. All countries set a "defacto" limit by segregating low-level from other wastes according to its source. The term "low-level" also encompasses numerous terms (intermediate, medium, low heat, short lived, etc.) and numerical definitions which have been given a meaning in specific applications. For example, intermediate-level often describes low-level wastes requiring shielding.

Classical engineering processes--evaporation, ion exchange, precipitation, compaction, incineration-are commonly employed to reduce volumes, as shown in Table 1. Clean liquids from the liquid treatment processes are discharged to the sea, nearby waterways, to the atmosphere as vapor, and to seepage trenches. Immobilization is employed, but not universally, to fix wastes for storage and/ or disposal. Cement and hitumen are the most common fixation agents, with plastics being used in isolated cases. 
TABLE 1. Practices Used for Treating Low-Level Radioactive Wastes

\begin{tabular}{|c|c|c|c|c|c|c|c|c|}
\hline & & & unge Reduct & & & & nobilizat & \\
\hline Country & $\begin{array}{l}\text { Evapo- } \\
\text { ration }\end{array}$ & $\begin{array}{c}\text { Ion } \\
\text { Exchange }\end{array}$ & $\begin{array}{c}\text { Precipi- } \\
\text { tation }\end{array}$ & $\begin{array}{l}\text { Compac- } \\
\text { tion }\end{array}$ & $\begin{array}{c}\text { Inciner- } \\
\text { ation }\end{array}$ & Cement & Bi tumen & Plastic \\
\hline Argentina & & & & 0 & $\bullet$ & & $\bullet$ & \\
\hline Austria & & & - & & - & $\bullet$ & & \\
\hline Belgium & - & - & 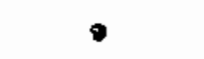 & - & $\bullet$ & $\bullet$ & $\bullet$ & $\bullet$ \\
\hline Brazil & & & & & & & & \\
\hline Bulgaria & - & - & 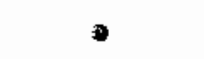 & & & & - & \\
\hline Canada & & - & & $\bullet$ & $=$ & & $\bullet$ & - \\
\hline China & ? & & - & & & $\bullet$ & - & $\bullet$ \\
\hline Czechoslovakia & - & - & - & $\bullet$ & & & $\bullet$ & \\
\hline Egypt & & & & & ? & 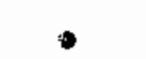 & & \\
\hline Finl and & $\bullet$ & - & & $\bullet$ & & $\bullet$ & $\bullet$ & \\
\hline France & ? & - & - & - & - & - & - & $\bullet$ \\
\hline Gemany (GDR) & $\bullet$ & - & - & $\bullet$ & & & $\bullet$ & \\
\hline Germany (FRG) & 2 & s & & - & - & $\bullet$ & & \\
\hline Hungary & a & - & - & & & & - & \\
\hline India & $\cdot$ & - & $\bullet$ & - & - & $\bullet$ & - & $\bullet$ \\
\hline Italy & - & - & - & 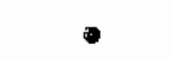 & - & - & - & \\
\hline Japan & - & & & ? & - & - & $\bullet$ & \\
\hline Korea & - & $\bullet$ & - & - & & $\bullet$ & $\bullet$ & \\
\hline Nether 1 ands & & & & & & & & - \\
\hline Pakistan & & & & & & & & \\
\hline Pol and & - & $\bullet$ & o & 0 & & & $\bullet$ & \\
\hline Rumania & $\bullet$ & - & $\bullet$ & - & & & - & \\
\hline South Africa & & & & & & . & & \\
\hline Spain & & & & $\bullet$ & - & - & & \\
\hline Sweden & & & & & & - & $\bullet$ & \\
\hline Switzerland & & & & & - & $\bullet$ & - & \\
\hline Taiwan & & & $?$ & - & - & $\bullet$ & 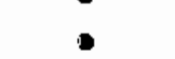 & \\
\hline United Kingdom & - & ? & - & - & - & $\bullet$ & & \\
\hline United States & a & - & $\bullet$ & - & & $\bullet$ & & \\
\hline USSR & ? & $\bullet$ & . & 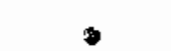 & & & - & \\
\hline Yugoslavia & ? & - & ? & & & & $\bullet$ & \\
\hline
\end{tabular}


Indefinite storage in surface structures and shallow-land burial are by far the most common methods of disposal, as shown in Table 2. Geologic repositories are used or planned in six countries that are characterized by the lack of surface area suitable for surface storage. Well injection of liquids is employed, but is not a standard practice, in both the United States and the IISSR. Ocean dumping was used recently by Belgium, the United Kingdom, and Switzerland, but is now held up by the moratorium agreed upon at the 1983 London Sea Dumping Convention.

Worldwide, the management of low-level waste appears to offer no serious difficulties. Commercially-available, classical engineering processes are being used worldwide to reduce and immobilize these wastes. Disposal to surface structures, shallow-land burial, and geologic repositories is being done widely with no apparent technical or environmental problems. 
TABLE 2. Practices Used for Disposing of Low-Level Radioactive Wastes

\begin{tabular}{|c|c|c|c|c|c|}
\hline \multirow[b]{2}{*}{ Country } & \multicolumn{5}{|c|}{ Disposal Practice } \\
\hline & $\begin{array}{l}\text { Surface } \\
\text { Facility }\end{array}$ & $\begin{array}{l}\text { Shallow } \\
\text { Burial }\end{array}$ & $\begin{array}{c}\text { Geologic } \\
\text { Repository } \\
\end{array}$ & $\begin{array}{c}\text { Well } \\
\text { Injection }\end{array}$ & $\begin{array}{l}\text { Ocean (a) } \\
\text { Dumping }\end{array}$ \\
\hline Argentina & - & & & & \\
\hline Austria & & & & & \\
\hline Belgium & & & & & 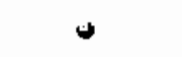 \\
\hline Brazil & & & & & \\
\hline Bulgaria & 0 & & & & \\
\hline Canada & $\bullet$ & o & & & \\
\hline China & & 0 & & & \\
\hline Czechoslovakia & 0 & & - & & \\
\hline Egypt & & 0 & & & \\
\hline Finland & & & & & \\
\hline France & 0 & $\bullet$ & & & \\
\hline Germany (GDR) & & & ० & & \\
\hline Germany (FRG) & & & o & & \\
\hline Hungary & 0 & & & & \\
\hline India & 0 & & & & \\
\hline Italy & $\bullet$ & 0 & & & \\
\hline Japan & 0 & & & & \\
\hline Korea & & 0 & & & \\
\hline Netherlands & & & & & \\
\hline Pakistan & & & & & \\
\hline Poland & 0 & & & & \\
\hline Rumania & 0 & & & & \\
\hline South Africa & & 0 & & & \\
\hline Spain & & & o & & \\
\hline Sweden & & & & & \\
\hline Switzerland & & & & & $v$ \\
\hline Taiwan & 9 & $\circ$ & & & \\
\hline United Kingdom & & 0 & & & 0 \\
\hline Inited States & & 0 & & 0 & \\
\hline IISSR & 0 & & & 0 & \\
\hline Yugoslavia & 0 & & & & \\
\hline
\end{tabular}

(a) No sea dumping has been performed since 1981 . 


\section{CONTENTS}

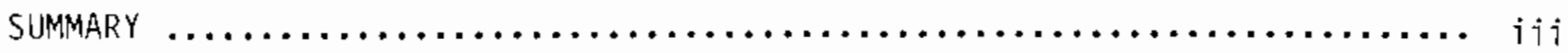

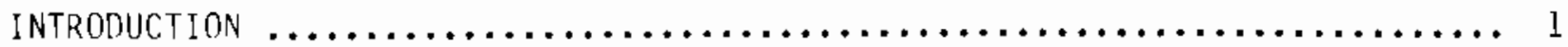

PRODUCTION OF LOW-LEVEL RADIOACTIVE WASTE $\ldots \ldots \ldots \ldots \ldots \ldots \ldots \ldots \ldots \ldots \ldots$

DEFINITIONS USED FOR LOW-LEVEL RADIOACTIVE WASTE $\ldots \ldots \ldots \ldots \ldots \ldots \ldots \ldots \ldots \ldots$

PRACTICES USED FOR TREATMENT AND DISPOSAL

OF LOW-LEVEL RADIOACTIVE WASTE $\ldots \ldots \ldots \ldots \ldots \ldots \ldots \ldots \ldots \ldots \ldots \ldots \ldots \ldots \ldots$

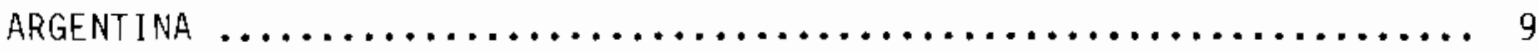

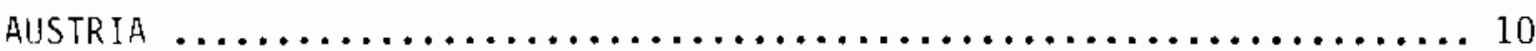

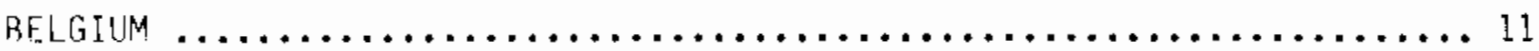

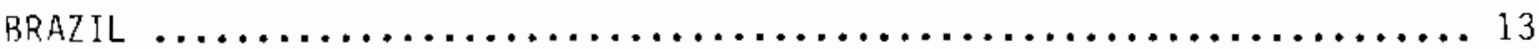

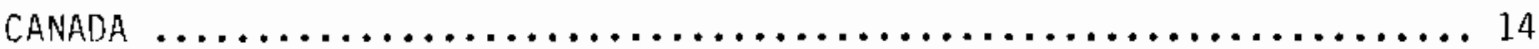

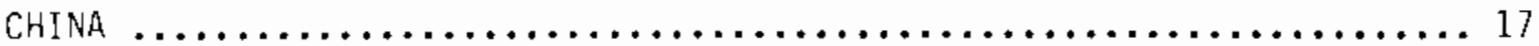

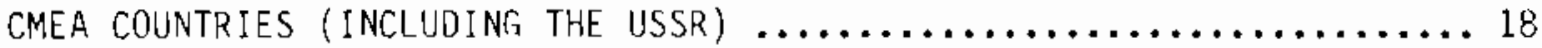

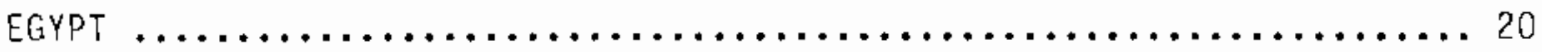

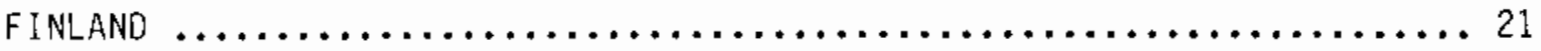

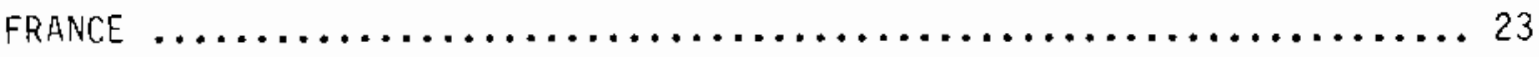

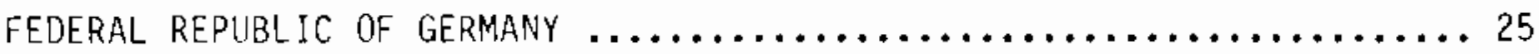

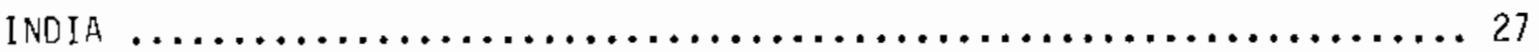

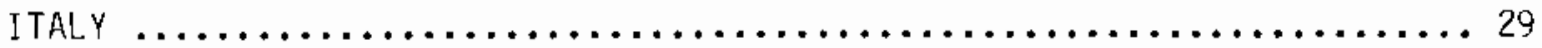

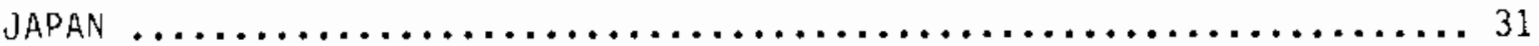

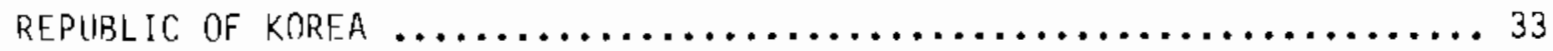

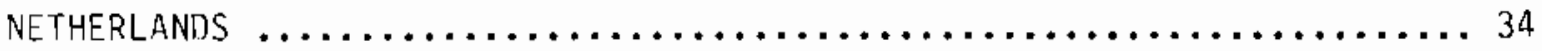

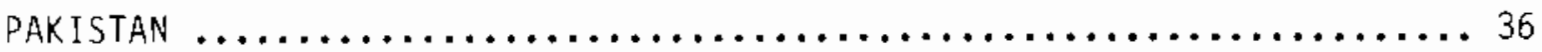

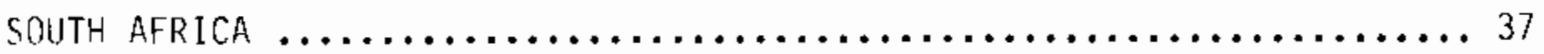

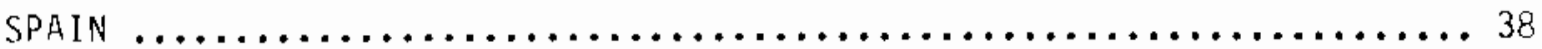




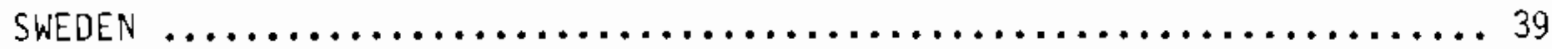

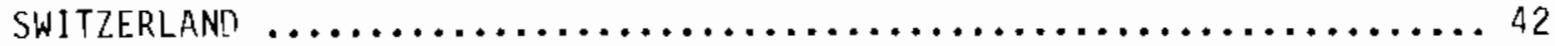

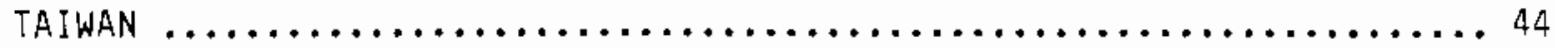

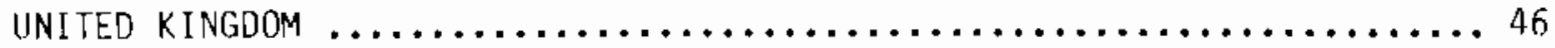

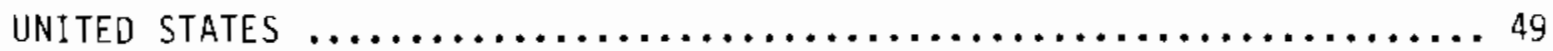

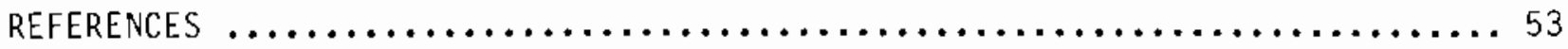




\section{INTRODUCTION}

This paper reviews the status of various practices used throughout the world for managing low-level radioactive wastes. Most of the information in this review was obtained through the DOE-sponsored International Program Support Office (IPSO) activities at Pacific Northwest Laboratory (PNL) at Richland, Washington. The objective of IPSO is to collect, evaluate, and disseminate information on international waste management and nuclear fuel cycle activities. The center's sources of information vary widely and include the proceedings of international symposia, papers presented at technical society meetings, published topical reports, foreign trip reports, and the news media. Periodically, the information is published in topical reports. (1)

Much of the information contained in this report was presented at the Fifth Annual Participants' Information Meeting sponsored by D0E's Low-Level Waste Management Program Office at Denver, Coiorado, in September of 1983. (2) Subsequent to that presentation, the information has been updated, particularly with information provided by Dr. P. Colombo of Brookhaven National Laboratory who corresponded with low-level waste management specialists in many countries.

The practices reviewed in this paper generally represent actual operations. However, major R\&D activities, along with future plans, are also discussed. 

Except for mine and milling wastes, low-level radioactive wastes represent the largest volume of the various classes of radioactive wastes produced. However, as shown in Table 3, they represent only a small fraction of the radioactivity.

Low-level wastes (as defined in the following section) arise in every phase of nuclear activities except mine and milling operations. Coming from a varied group of producers, low-level wastes vary widely in physical and chemical characteristics. They are similar to nonradioactive industrial and institutional (I/I) wastes except for contamination by radionuclides. They include organic and inorganic material, equipment, clothing, paper, sludges, wood, plastics, carcasses, or anything considered waste.

As shown in Table 4 , the largest current source of low-level radioactive wastes in the United States is defense-related activities, closely followed by power reactor operations and $\mathrm{I} / \mathrm{I}$ activities. The latter sources are growing more rapidly, however, than defense activities. In non-weapons countries, of course, there would be no defense activities generating radioactive wastes. The production of low-level waste is also a function of the degree of involvement in nuclear power generation. All countries produce some low-level radioactive waste from institutional/industrial activities--the quantities being dependent on the technological development of the country.

\section{TABLE 3. Comparison of Volume and Radionuclide Content} of Various Wastes

\begin{tabular}{|c|c|c|}
\hline Waste Stream & $m^{3} / G W e-y r$ & $\mathrm{Ci} / \mathrm{GWe}-\mathrm{yr}$ \\
\hline High-level waste as: & & \\
\hline Unreprocessed spent fuel & $\sim 14$ & $\sim 1 \times 10^{8}$ \\
\hline Solidified high-level waste & $\sim 2$ & $\sim 1 \times 10^{8}$ \\
\hline TRIJ waste & $\sim 150$ & $\sim 1 \times 10^{4}$ \\
\hline Low-level waste & $\sim 3,000$ & $\sim 5 \times 10^{4}$ \\
\hline Mill tailings & $\sim 40,000$ & $\sim 5 \times 10^{2}$ \\
\hline
\end{tabular}



TABLE 4. Projecteg U.S. Sources of Low-Level Radioactive Wastes
in $1984(3)$

\begin{tabular}{lccc}
\multicolumn{1}{c}{ Source } & Volume $\left(\mathrm{m}^{3} / \mathrm{yr}\right)$ & Activity (Ci/yr) \\
Institutional/Industrial & 31,500 & & 426,600 \\
Reactor Operation & 51,400 & 80,700 \\
Fuel Cycle & 6,600 & 27 \\
Defense Activities & $\underline{76,500}$ & $\underline{1,358,000}$ \\
Totals & 166,000 & $1,865,327$
\end{tabular}

Estimated volumes of low-level radioactive wastes expected to be accumulated in selected countries are shown in Table 5. The volumes depend heavily on the scope and types of nuclear activity under way in a country. The United States, having the greatest number of power reactors and an extensive involvement in the fuel cycle, is the greatest producer. Canada, a prime source of uranium conversion, generates a significant quantity $(67 \%)$ of its low-level wastes in that activity.

TABLE 5. Estimated Cumulative Production of Low-Level Radioactive Waste in Selected Countries by the Year 2000

\begin{tabular}{lr}
\multicolumn{1}{c}{ Country } & Quantity $\left(\mathrm{m}^{3}\right)$ \\
\hline Canada & $419,000^{(4)}$ \\
France & $800,000^{(5)}$ \\
Japan & $360,000^{(6)}$ \\
United Kingdom & $580,000^{(7)}$ \\
United States & $7,100,000^{(3)}$ \\
Switzerland (by year 2040 or & $160,000^{(8)}$ \\
$\quad 6,000$ fiwe production) &
\end{tabular}




\section{DEFINITIONS USED FOR LOW-LEVEL RADIOACTIVE WASTE}

Around the world, many terms are used to denote certain classes of radioactive waste by source or characteristics. Typical examples, all prefacing the word "wastes," include:

$\begin{array}{ll}\text { high-level } & \text { beta-gamma } \\ \text { intermediate-level } & \text { alpha } \\ \text { medium-levei } & \text { transuranic } \\ \text { low-level } & \text { high-heat } \\ \text { very low-level } & \text { low-heat } \\ \text { reactor } & \text { long-life }\left(\mathrm{t}_{1 / 2}>30 \mathrm{yr}\right) \\ \text { fuel cycle } & \text { short-life }\left(\mathrm{t}_{1 / 2}<30 \mathrm{yr}\right) \\ \text { institutional } & \end{array}$

The term "low-level" is increasingly used to describe a major group of these wastes, that is, those beta-gamma contaminated wastes having relatively short lives, though possibly requiring shielding and generating significant heat. This definition is generally similar to that quoted in the U.S. LowLevel Waste Policy Act passed December 23, 1980. By this definition, low-level radioactive wastes include all radioactive wastes emanating from the nuclear fuel cycle, weapon material programs, and institutions, except mine and mill tailings, spent fuel, high-level, and transuranic-contaminated wastes.

Within a given facility or operation, segregation is often practiced to facilitate handling or storage, i.e., separation of waste that may be handled directly from that requiring shielding. Criteria used for this segregation are established by the producers/handlers and can vary from situation to situation. Segregation by source without regard to criteria is also commonly used; for example, all power station wastes except spent fuel are considered to be low-level waste in the U.S.

A few countries have established radioactivity limits for shallow-land burial or for sea dumping which, in effect, define low-level wastes. These limits are summarized in Table 6. It is evident that the alpha or TRU content is a major criterion, reflecting the importance of radionuclide longevity on 
TABLE 6. Radioactivity Limits Used for Disposal of Low-Level Radioactive Waste

\begin{tabular}{|c|c|c|c|c|}
\hline \multirow[b]{2}{*}{ Country } & \multicolumn{4}{|c|}{ Disposal Method } \\
\hline & $\begin{array}{c}\text { Shallow-Land } \\
\text { Burial }\end{array}$ & Sea & Dumping & $\begin{array}{l}\text { Release to } \\
\text { Environment } \\
\text { (de minimis) }\end{array}$ \\
\hline Belgium & -- & $\begin{array}{r}100 \mathrm{Ci} \\
1 \mathrm{Ci}\end{array}$ & $\begin{array}{l}\beta-\gamma / t^{(12)} \\
T R U / t\end{array}$ & -- \\
\hline Canada & -- & & -- & $\begin{array}{c}<100 \mathrm{pCi} / \mathrm{m}^{3(9)} \\
\text { (proposed) }\end{array}$ \\
\hline $\begin{array}{l}\text { Czechoslovakia } \\
\text { established }(10)\end{array}$ & - & & -- & Value \\
\hline France & $<0.1 \mathrm{Ci}$ TRU $/ \mathrm{m}^{3(11)}$ & & -- & - \\
\hline IAEA & -- & $\begin{array}{r}100 \mathrm{Ci} \\
1 \mathrm{Ci}\end{array}$ & $\begin{array}{l}\beta-Y / t^{(12)} \\
T R U / t\end{array}$ & Under study $(16)$ \\
\hline India & $\begin{array}{l}1 \mu \mathrm{Ci} \mathrm{TRU} / \mathrm{ft}^{3(13)} \\
25 \mathrm{dpm} \mathrm{TRU} / \mathrm{cm}^{2}\end{array}$ & & -- & - \\
\hline Japan & -- & & -- & Under study $(6)$ \\
\hline United Kingdom & $\begin{array}{ll}20 \mathrm{mCi} & \mathrm{TRU} / \mathrm{m}^{3(14)} \\
60 \mathrm{mCi} & B-\gamma / \mathrm{m}^{3}\end{array}$ & $\begin{array}{r}100 \mathrm{Ci} \\
1 \mathrm{Ci}\end{array}$ & $\begin{array}{l}B-Y / t(12) \\
T R U / t\end{array}$ & $10^{-5} \mu \mathrm{Ci} / \mathrm{g}^{(18)}$ \\
\hline United States & $\begin{array}{l}\text { 10-100 nCi } \\
\text { TRU/g(15) }\end{array}$ & & -- & Under study (17) \\
\hline $\begin{array}{l}\text { USSR } \\
\text { established }(10)\end{array}$ & -- & & -- & Value \\
\hline
\end{tabular}

the choice of disposal method. The sea dumping performed by the United Kingdom, Switzerland, and Belgium adheres to the IAEA guidelines for sea disposal. Only two upper limits on beta-gamma activity were noted in the literature--the $60 \mathrm{mCi} \beta-\gamma / \mathrm{m}^{3}$ for burial in the United Kingdom burial ground at Drigg and the $100 \mathrm{Ci} B-\gamma / t$ set by the IAEA for sea dumping. The former criterion is believed to be set by handling requirements. The latter or IAEA criterion is a limit on 
release rate, as the IAEA limit on beta-gamma concentration is accompanied by an annual dumping limit of 100,000 tonnes.

Except for three countries, United Kingdom, Czechoslovakia and the USSR, no lower or de minimis limits are used to define low-level wastes. The United Kingdom uses $10^{-5} \mu \mathrm{Ci} / \mathrm{g}$ as the deminimus level; the values used in Czechoslovakia and the USSR were not quoted in the literature. It is suspected that considerable segregation of radioactive from nonradioactive waste is, in effect, done by segregating wastes according to source; i.e., wastes from nonnuclear operations are not mixed with waste from nuclear operations. Because of their interest in minimizing waste quantities from nuclear operations, more countries are seeking to establish lower or de minimus limits. Canada has proposed a value of $<100 \mathrm{pCi} / \mathrm{m}^{3}$, and Japan and the United States are known to be working on the topic. 


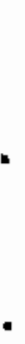

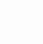


PRACTICES USED FOR TREATMENT AND DISPOSAL

OF LOW-LEVEL RADIOACTIVE WASTE

Practices employed for managing low-level radioactive wastes vary considerably among nations, depending upon three factors--extent of the nuclear energy program, state of industrial development, and geography. Patterns or preferences are energing, however, as is evident in the following summaries.

Argentina $(18-21)(a)$ has operated a 335-MWe pressurized heavy water reactor (PHWR) since 1974 and began operation of a 600-MWe PHWR in April 1983. Another PHWR is under construction; four others are planned. Small-scale experimental programs have been under way on fuel fabrication and fuel reprocessing for several years, with larger-scale facilities now being completed at the Ezeiza Atomic Center. A heavy water plant is under construction and the first module of a gaseous diffusion enrichment plant began operation in 1983 .

Low-level radioactive waste (LLW) is defined in Argentina as that waste which contains less than $0.01 \mathrm{Ci} / \mathrm{m}^{3}$. Medium-level waste (MLW) contains greater than $0.01 \mathrm{Ci} / \mathrm{m}^{3}$ and less than $100 \mathrm{Ci} / \mathrm{m}^{3}$. In practice a maximum contact dose for low-level solid wastes is $150 \mathrm{mR} / \mathrm{hr}$.

Low-level radioactive wastes produced by the PHWR type of reactor are similar to those from light water reactors (LWR) but are smaller in quantity because of efforts to conserve heavy water through leakage control. Typicaliy, however, a PHWR generates more tritium and ${ }^{14} \mathrm{C}$ in the waste than does a LWR. Low-level wastes are also generated by uranium mining, fuel production, isotope generation and by laboratories of the Constituyentes Atomic Center (CEC) and the Ezeiza Atomic Center (CAE) as well as other outside users of radionuclides. The volume of solid wastes is $70 \mathrm{~m}^{3} / \mathrm{yr}$ while the volume of liquid waste is $200 \mathrm{~m}^{3} / \mathrm{yr}$. Wastes from the operating reactor and research activities are collected at the Ezeiza Atomic Center, which operates a waste depository (storage facility), a small solidification plant for liquid wastes, and an incinerator for combustible wastes.

(a) Dr. Roberto Gabarain, Dpto. Ingenieria de Plantas Quimicas, Comision National De Energia Atomica, Avda. del Liberator 8250, Buenos Aires, Argentina (private communications). 
Liquid wastes are stored in tanks where they are allowed to decay prior to disposa1. Only a small volume of medium-level liquid waste generated at the Atucha Nuclear Power Station is solidified and then treated as solid waste. Solid wastes containing radionuclides with half-lives of less than 5 years are either incinerated or compacted. Incinerator ash is solidified with bitumen. All compactable waste is treated directly in 200- $\ell$ drums. Waste that has been solidified also is packaged in 200- $\ell$ drums as well as any solid waste which is neither combustible nor compactible.

Liquid wastes are discharged into trenches which have been constructed in well-characterized clays, known to have good radionuclide retention capabilities. Solid wastes are disposed of by shallow-land burial.

Austria $(22)(a)$ has given the responsibility for managing radioactive wastes to the Austrian Atomic Energy Research Company (SGAE). Their laboratory at Seibersdorf was designated by the Austrian Ministry of Health and Environmental Protection, in April 1982, to receive, treat and store all radioactive waste. Low-level radioactive wastes (LLW) in Austria are not defined clearly by law. According to health physics regulations, several levels of protection must be followed when dealing with different amounts of radionuclides, depending on their radiotoxicity. For practical purposes, the definitions in the IAEA transport regulations are used. For LLW, the surface dose of an unshielded waste material must be less than $200 \mathrm{mrem} / \mathrm{hr}$ or the specific activity must be less than the values for low specific activity (LSA) wastes. wastes with higher activities are designated medium-level wastes (MLW).

Austria generates low-level radioactive wastes through its medical, industrial, and research activities. Though completed, the 692 MWe BWR at Tullnerfeld is prevented from operating by a negative plebiscite in 1978. Reactor wastes are produced at three research reactors, however. Much of the liquid waste received at Seibersdorf is generated by medical institutions and consists of excreta, isotope generator rinsing solutions and scintillation liquids. This waste is sent to the treatment facility in 25-l drums. Most of the liquid waste from the research reactors is treated as normal radioactive waste but

(a) Dr. Peter Patek, Österreichische Studiengesellschaft für Atomenergie Ges.m.b.H, Lenaugasse 10, A-1082 Wien, Austria (private communications). 
liquids resulting from ion-exchange resin bed regeneration require special handling because of their high activity. Currently, 10,000 Ci of ${ }^{60} \mathrm{Co}$ sources and $20,000 \mathrm{Ci}$ of research reactor wastes are stored in hot cells prior to conditioning.

During the first half of 1983, the radioactive waste generated in Austria was composed primarily of: $12,000 \mathrm{~kg}$ of combustible solids, $14 \mathrm{~m}^{3}$ of noncombustible solids and $940 \mathrm{~kg}$ of biological wastes. Approximately 8000 fume detectors have also been collected since 1981 due to a recall of old detectors. Wastes containing uranium and transuranic isotopes are generated at the rate of $600 \ell / y r$ at the Safeguards Analytical Laboratory of the IAEA in Vienna.

Treatment of low-level wastes at Seibersdorf includes incineration, compaction, flocculation, filtration, cementation, and bituminization. It is planned to install a small evaporator in the waste treatment facility at Seibersdorf, which will have a throughput of $10 k / h r$. Plans also exist for installation of a continuous flow centrifuge for filter sludges.

Conditioned wastes are packaged in 200- $\ell$ drums. Currently, the conditioned low-level wastes are placed into a temporary storage facility measuring $18 \mathrm{~m}$ by $40 \mathrm{~m}$ at Seibersdorf. Unconditioned and newly arrived wastes are kept in 8 compartments of $7 \mathrm{~m}$ by $12 \mathrm{~m}$. As yet, a means of final disposal has not been selected.

Belgium $^{(23-27)(a)}$ has an active program for the development of nuclear power. Five pressurized water reactors are operating and two are under construction. When all are operating in 1986, nuclear power will provide about $60 \%$ of the country's electrical needs. Supporting fuel cycle activities in Belgium include the fabrication of uranium fuel for water-cooled reactors (the FBFC plant at Dessel), the fabrication of mixed uranium-plutonium fuel for water-cooled reactors and fast breeders (Belgonucléaire's plant at Dessel) and the past and possibly future reprocessing of spent fuel in the Eurochemic plant, which is also at Dessel. As is well known, the latter plant discontinued reprocessing in 1974 but will reopen following the Parliament's recent favorable decision. Also, the Institut des Radioelements (IRE) at Fleurus

(a) J. van Dievoet, General Manager, Belgonucleaire, Rue du Champ de Mars, 25-B-1050 Brusseis, Belgium (private communications). 
produces specific fission-product radioisotopes. The responsibility for managing the radioactive wastes produced in these activities belongs to a public agency, "0rganization for the Management of Radioactive Waste and Fissile Materials (NIRAS/ONDRAF)." The costs of managing radioactive wastes are borne by the waste producers.

Belgium, because it disposes of its low-level waste at sea, must conform to IAEA regulations for ocean dumping, including the IAEA definitions for lowlevel radioactive waste as they pertain to ocean disposal. For treatment purposes, the Belgian Study Center for Nuclear Energy (CEN/SCK) divides low-level wastes into two categories ranging from $10^{-5}$ to $1 \mathrm{ci} / \mathrm{m}^{3}$. Waste containing more than $1 \mathrm{ci} / \mathrm{m}^{3}$ is considered to be intermediate-level waste requiring shielding.

Low- and intermediate-level wastes are generated at the operating nuclear power stations and a number of research and fuel cycle facilities. In 1982 the 5 operating power plants produced approximately 6000 drums $(200-\ell)$ of solidified liquid waste and 200 drums of solid wastes such as ion-exchange resins and filters. The nuclear site at Mol contains a number of facilities including the Study Center for Nuclear Energy, a $\mathrm{U}_{2}$ fuel fabrication plant (FBFC), a mixed oxide fuel reprocessing plant (Belgonucleaire), the Eurochemic fuel reprocessing plant and a Euratom research center. The central LLW processing plant at CEN/SCK alone treats approximately $195,000 \mathrm{~m}^{3}$ of 1 iquid waste and 4,500 $\mathrm{m}^{3}$ of solid waste annually. In 1982, hospitals, research institutes and industrial facilities generated 3000 drums of solidified liquid waste and 1200 drums of solid waste.

Essentially all of the low-level waste generated in Belgium is treated at a centralized processing plant operated by CEN/SCK at Mol. All low-level wastes generated at the various facilities at Mol and all solid waste from power plants are sent to this central location. Liquid wastes are concentrated mainly by coprecipitation and flocculation and then solidified in bitumen. Solid wastes are either compacted into bales or incinerated. Liquid wastes from power plants are solidified in cement at the power plant. Intermediatelevel wastes from the fuel reprocessing plant at Mol are conditioned near the reprocessing facility with bitumen and also stored at that site. 
Wastes are packaged in 200- $\ell$ or $400-\ell$ galvanized steel drums, or $1 \mathrm{~m}^{3}$ concrete containers. The packages are color coded according to activity, inventoried and placed into storage awaiting an ocean disposal campaign. Storage has been in open air but there is now indoor storage for 10,000 tonnes of waste. Low-level wastes are kept in interim storage for 1-2 years at power plant sites or at CEN/SCK prior to disposal. Intermediate-level wastes, which are not suitable for ocean dumping because of their high activities, are stored in above ground bunkers that have been engineered for a storage period of 50 years.

Ocean disposal has been the principal means of discarding low-level waste in Belgium. For example, in 1981 Belgium dumped 4,450 tonnes of waste meeting the IAEA criteria at the Northeast Atlantic disposal site. This waste contained 9,361 Ci of activity most of which were beta-gamma emitters. Future disposal of dumping at sea is uncertain because of the moratorium agreed upon at the 1983 London Sea Dumping Convention. Intermediate-level wastes which cannot be disposed in the ocean will eventually be placed in a shallow-land burial site or in clay beds found at $200 \mathrm{~m}$ depth beneath Mol.

Brazil $^{(28,29)(a)}$ operates one 626-MWe PWR (Angra I) and is building two others with anticipated startup dates in the late eighties. In addition, the Brazilian Nuclear Energy Commission (CNEN) operates three research reactors and supports three nuclear institutes with programs ranging from pure research to industrial development of uses of atomic energy. These institutes are in charge of training personnel, research and development activities, radioisotope production and technical support for CNEN.

The CNEN is the governmental agency responsible for licensing, inspections and procedures at fuel cycle facilities and at the Angra I nuclear power piant. Currently Brazil is adhering to the 1970 IAEA classifications for low-level radioactive waste. Most low-level waste is generated at the Angra I nuclear power plant. It is estimated that this plant generates 678 drums $(200 \&)$ of trash, 1770 drums of evaporator bottoms and ion-exchange resins and 32 drums of

(a) H. R. Frazen, Waste Management Leader, Comissao Nacional de Energia Nuclear (CNEN), Rua General Severiano, 90-Botafogo, Rio de Janeiro, Brazil (private communications). 
filters. Approximately $1-5 \mathrm{~m}^{3}$ of trash and filters are expected to be generated at a fuel element production facility. Other low-level wastes are generated at the research establishments as well as at medical and industrial facilities.

Solifidication of evaporator bottoms from the Angra I power plant takes place with a vermiculite/cement matrix in 200-l drums. Solid wastes are compacted in 200-l drums. Liquid wastes containing significant activity are stored prior to being conditioned with a solidification agent which is currently under study.

Al1 wastes are packaged in 200-l carbon-steel drums and are stored at the generation site until a decision is made regarding disposal.

The intention in Brazil is to dispose of LLW by shallow-land burial. Currently, site feasibility studies are being conducted by CNEN to determine where disposal should take place. Lowest activity liquid wastes are currently released to the environment in accordance with radiological protection standards.

Canada, $(30-32)(a)$ an industrialized country with an active nuclear energy program, produces low-level radioactive wastes through its nuclear fuel cycle activities, research programs, and institutional use of radioactive materials. Based upon the CANDU natural uranium fuel reactor system, Canadian fuel cycle activities include only mining and milling, uranium refining, fuel fabrication, and reactor operations (13 reactors). Commercial nuclear power activities are handled primarily by two organizations: a government corporation, Atomic Energy of Canada Limited (AECL), and Ontario Hydro, a utility which operates most nuclear power stations. The Atomic Energy Control Board (AECB), a government agency with responsibility for regulatory and environmental oversight, licenses all facilities that are involved in radioactive waste management. It is assisted by the Federal Department of the Environment and the Ontario Ministry of the Environment.

(a) D. H. Charlesworth, head, Chalk River Environmental Authority, Atomic Energy of Canada Limited, Chalk River Nuclear Laboratories, Chalk River, Ontario (private communications). 
Low-level waste is typically defined in Canada as that radioactive material which does not require shielding. The limiting dose rate may vary depending on health physics regulations at the generation sites. Intermediatelevel waste is radioactive waste which requires shielding.

Excluding mine and milling wastes, uranium refining represents the largest source of low-level wastes $\left(4500 \mathrm{~m}^{3} / \mathrm{yr}\right)$, followed by reactor operations $\left(1300 \mathrm{~m}^{3} / \mathrm{yr}\right)$, with fuel fabrication $\left(510 \mathrm{~m}^{3} / \mathrm{yr}\right)$, research activities $\left(520 \mathrm{~m}^{3} /\right.$ $\mathrm{yr})$, and institutional sources $\left(300 \mathrm{~m}^{3} / \mathrm{yr}\right)$ contributing lesser amounts. The PHWR used in Canada typically produce lower waste volume than a light water reactor but the PHWR waste contains significantly more ${ }^{14} \mathrm{C}$ and tritium. Isotope production is relatively important in Canada where approximately 60\% of the world supply of isotopes is prepared by reactor irradiation. Fuel reprocessing, which was a small-scale operation, was terminated by 1960 .

Essentially all low-level radioactive wastes are collected at seven waste management areas to be stored retrievably. Reactor wastes are collected at the major reactor sites--Bruce site for Ontario Hydro, Gentilly site for Hydro Quebec, and H. Lepreau for the New Brunswick Electric Power Commission. Research wastes are collected at the two major R\&D centers at Chalk River and Whiteshel1. Institutional wastes are collected at Chalk River, and Eldorado Resources, Ltd., is operating two storage sites for uranium refinery wastes and is planning a disposal facility for these wastes.

Treatment practices are evolving, with the major sites now establishing waste treatment centers. Since 1977, Ontario Hydro has been operating a Waste Volume Reduction Facility at the Bruce site. Solid wastes are sorted into three categories--incinerable, processible, and nonprocessible. The wastes in the first two categories are either incinerated or compacted, and then put into storage in rectangular packages. Between 1977 and 1982 the Waste Volume Reduction Facility at the Bruce site has incinerated over $10,000 \mathrm{~m}^{3}$ of LLW from all Ontario Hydro reactors. A volume reduction by an average factor of 40 is achieved. Approximately $5000 \mathrm{~m}^{3}$ of LLW has also been compacted and bailed with volume reduction factors between 4.5 and 9 achieved. At the Chalk River research center, $230 \mathrm{~m}^{3}$ of solid low-level waste have been incinerated and $400 \mathrm{~m}^{3}$ compacted by the middle of 1982 . The incinerator ash is immobilized in 
bitumen. In an expansion of the treatment facilities, ultrafiltration and reverse osmosis systems are being added to concentrate low-level liquid wastes that have been discharged to seepage pits since 1946. The concentrates will be immobilized in bitumen with the incinerator ash. Intermediate-level waste is not processed. At the Whiteshell research site (WNRE), the Active Liquid Waste Treatment Center, which employs a rising-film evaporator to concentrate intermediate-level liquid waste, has been constructed. The sludge from the evaporator is solidified in polyester resin. Tritium is a major radionuclide released into the off-gas system of CANDU reactors. A process is under development to concentrate molecular tritium as a metal tritide which can then be stored or disposed.

As with treatment, storage practices vary and are evolving. Shallow-land burial is being phase out in favor of engineered storage structures. Wastes are generally packaged in $1 \mathrm{~m}^{3}$ or $3 \mathrm{~m}^{3}$ rectangular containers in order to make the most efficient use of storage and disposal space. Drums have only limited use. Some low-level trash is packaged in plastic bags. Small institutional users of radioisotopes often use 5-gallon cans for waste packaging.

Canada's largest waste storage operation is the centralized facility of Ontario Hydro at their Bruce Nuclear Power Development (BNPD). This receives about $3000 \mathrm{~m}^{3} / \mathrm{yr}$ of $10 \mathrm{w}$ - and intermediate-level solid wastes from the five reactors operating on the site and the four Pickering $\mathrm{A}$ reactors $250 \mathrm{~km}$ away.

At the Radioactive Waste Operations Site, which has been in use by Ontario Hydro since 1974, several types of concrete containment structures have been used, based on the handling requirements of the various packages. Initially, the low-level wastes, which are usually packaged in clear polyethylene bags and do not require shielding during handling, were stored in large concrete-lined trenches set in the ground. Wastes with significant radiation fields, such as ion-exchange resins or filter canisters, were unloaded from flasks directly into waterproof "tileholes," concrete pipes set vertically on a foundation pad in the ground with the top opening almost flush with the ground surface. The tileholes and trenches are well above the water table and are fitted with an under-drain system leading to a monitored and controlled discharge. With experience, containment-structure design has evolved, the current trend being 
to construct the storage facilities above ground rather than buried. The latest facility, a prestressed, prefabricated concrete storage building, will reduce the cost of storing low-level wastes by a factor of three while reducing land consumption by a factor of ten compared to in-ground trenches.

At other waste management sites located at nuclear power stations, the storage structures have also been adapted to suit local conditions. At the Gentilly site of Hydro Quebec, since the water table is at shallow depth, the concrete trenches and storage blocks were built in raised earth mounds. At Pt. Lepreau, the coastal site of the New Brunswick Electric Power Commission, there is little overburden and the storage blocks and bunkers are built on the bedrock, completely above ground.

Nuclear research sites now store their more radioactive wastes, other than spent fuel, in below-ground concrete structures, with shorter-lived wastes being placed in monitored shallow-land burial trenches. These include radioactive wastes from the manufacture of nuclear fuel and from medical and industrial uses of radioisotopes which are shipped to Chalk River for management along with site-generated wastes.

China $(33)(a, b)$ has no nuclear power production but generates low-level radioactive wastes through weapon material production activities and institutional uses of radionuclides. The former activities include mining, uranium extraction and enrichment, fuel fabrication and reprocessing. Institutional uses include operations in laboratories, medical institutions, universities and industrial facilities utilizing radionuclides. While there are no power reactors in operation, wastes are generated by numerous research reactors. No data on generation rates and total amounts of LLW are available.

Radioactive wastes are treated at the facility where they are generated. The Ministry of Nuclear Industry is directly responsible for waste treatment in cooperation with the Public Health Ministry. The newly formed Ministry of

(a) Unpublished notes on visit of 5-man team from the People's Republic of China to Nuclear Fuel Services, Pacific Northwest Laboratory, Oak Ridge National Laboratory, Brookhaven National Laboratory, Bechtel, Inc., and U.S. DOE Headquarters, May 1982.

(b) Mr. Lu Guangyi, Deputy Secretary-General, Chinese Nuclear Society, P.0. Box 2125, Beijing, China (private communications). 
Urban and Countryside Construction and Environmental Protection issues management regulations and supervises low-level radioactive waste management nationwide. A11 of these ministries are subordinate to the State Council. Most facilities utilize the 1970 IAEA classifications for low- and internediatelevel wastes. In practice some facilities utilizing radioactive materials take $<10^{-5} \mathrm{Ci} / \ell$ as low-level liquid waste while $10^{-3}$ to $10 \mathrm{Ci} / \mathrm{l}$ is considered intermediate-level waste

Liquid radioactive waste is treated primarily by precipitation to bring the aqueous activity levels to $10^{-5} \mathrm{ci} / \ell$. Evaporation is then utilized to further reduce activity to $10^{-10} \mathrm{Ci} / \mathrm{l}$. Ion-exchange processes then bring activity leveis to $7 \times 10^{-11} \mathrm{Ci} / \ell$ while electro-dialysis and reverse osmosis may also be used for further purification prior to reuse or release of waste water to the environment. Solid combustible wastes are incinerated. cement, bitumen and plastics are being developed as solidification agents.

After decontanination liquid wastes are diluted and released to waterways. Some wastes are also pumped to evaporation ponds. Short half-life materials are allowed to decay in storage. Longer-lived isotopes are disposed of by burial or by disposal in deserted mines or in natural caves.

Research is being conducted on effective volume reduction techniques and safe storage and disposal. Cement, bitumen and plastic solidification processes have been developed at the pilot plant scale and are being brought to full-operational scale.

\section{CMEA ${ }^{(34-43)(a)}$ (Council for Mutual Economic Assistance) countries,} include the foilowing countries with centrally planned economies--Bulgaria, Czechoslovakia, the German Democratic Republic, Hungary, Poland, Rumania, USSR, and Yugosiovia. Out of this group, only the USSR produces nuclear weapon material. These countries operate 58 reactors: most (44) are in the USSR; others are in Bulgaria (4), the German Democratic Repuilic (5), Czechoslovakia (3), rlungary (1), and Yugoslavia (1).

(a) Dr. György Vajda, Uirector, Institute for Electrical Power Research, Zrinyi U1.1, P.0. Box 233, H-1363,1051, Budapest, Hungary (private communications). 
As these reactors are mostly supplied by the USSR (except the Westinghouse unit in Yugoslavia), waste management policies in the CMEA countries tend to follow the USSR lead. The policy seems to be one of using the treatment and disposal means best suited to the local situation. Onsite storage is relied on to a great extent.

In the CMEA countries, the responsibility for the management of low-level radioactive waste rests with an appropriate state agency. In Hungary, the Radioactive Waste Processing and Storing Department of Budapest (KÖjÁL/Public Health and Pest Control Station of the Ministry of Health has overall responsibility for the collection, processing and disposal of radioactive waste.

The available literature describing the nuclear activities in the CMEA countries indicates various treatments are employed. Evaporation, ion exchange, and chemical conditioning are widely used to reduce volumes of lowlevel liquid wastes. Bitumen appears to be a common fixation agent employed for liquid concentrates and resins; however, cement is also used with lower activity wastes. Cement is to be used at the two 440 Mwe nuclear power plants operating in Hungary. These reactors are expected to generate each year $400 \mathrm{~m}^{3}$ to $600 \mathrm{~m}^{3}$ of evaporator bottoms, $100 \mathrm{~m}^{3}$ of spent ion-exchange resin and $200 \mathrm{~m}^{3}$ of solid waste, $80 \%$ of which is compactible. Little mention is made of the treatment of solid wastes except for the use of compaction. A compactor, producing bales $0.9 \mathrm{~m}$ by $0.6 \mathrm{~m}$ by $0.7 \mathrm{~m}$, is used at the Czechoslovak reactor near Bohunice. Compaction is also used at Hungary's reactors. Incinerators are generaliy not used in the CMEA countries; however, an electric furnace is used to incinerate waste at the central waste disposal station at Zagorsk, near Moscow.

As with waste treatment, the CMEA countries are exploring and using several disposal methods. Injection of radioactive liquids into underground strata has been used, but it is not certain that such practices are continuing. Storage of solid wastes in concrete structures at the generator's site is a common practice. For example, the compacted bales produced in the Czechoslovak reactor are stored onsite in a concrete pit. In Hungary, treated wastes are stored temporarily in specially-built indoor facilities at the generation site. Following approximately one month of temporary storage, the 
wastes are transported to the Radwaste Processing and Disposal Plant at Puspokszilagy. The solidified wastes are transported in $200-\ell$ mild steel drums. There, wastes are disposed in underground reinforced concrete $70 \mathrm{~m}^{3}$ boxes. Solidified waste, including treated biological wastes are placed in the boxes and the void spaces between packages are filled with cement-liquid (LLW) slurries. Treated organic wastes are placed in underground concrete containers. Hungary has not yet selected a site for the final disposal of lowand medium-level wastes. Final disposal, however, will be by shallow land either with or without watertight reinforced concrete trench iiners. Rock cavity repositories for solid low- and intermediate-level wastes are in operation in Czechoslovakia (Iimestone), and the German Democratic Republic (salt). A similar repository is being considered in Yugoslavia (shale). Egypt $^{(44)(a)}$ generates low-level radioactive wastes through its research, medical and industrial activities. For example, wastes are generated at a $2-M W$ research reactor, in isotope production facilities and through metallurgy research. To manage these wastes and to meet existing demands for training specialists, an experimental radioactive waste management station is now under construction at the Nuclear Research Center, located at Inchas near Cairo. No power reactors are operating although two 900-MWe PWRs are planned within the next decade.

At the Inchas site, low-level liquid wastes will be treated by chemical coagulation and ion-exchange. Intermediate-level liquid wastes are to be treated by evaporation. Ion-exchange regeneration liquids and sludges from treatment of liquid wastes will be solidified with cement. Solid wastes will be subject to incineration or volume reduction before conditioning and disposal. Waste conditioned with cement is poured into concrete shells which have a wall thickness of $10 \mathrm{~cm}$. Each container holds $4200 \&$ of the waste/cement mixture.

The disposal facility for low- and intermediate-level waste consists of engineered covered concrete trenches. Each trench is $56 \mathrm{~m}$ long, $10 \mathrm{~m}$ wide

(a) Dr. N. Ghattas, Radioisotope Department, Atomic Energy Authority, DOKKI, Cairo, Egypt (private communications). 
and $3 \mathrm{~m}$ deep with a $30 \mathrm{~cm}$ portion of the walls rising above ground level and can hold 150 concrete shells.

Finland $(35,45-47)(a)$ generates low-level radioactive wastes at its nuclear power reactors (four), at the research centers at Espoo near Helsinki, and through institutional uses of radioactive materials. The Finnish government oversees nuclear affairs through the Atomic Energy Commission, which is a component of the Energy Department in the Ministry of Trade and Industry. In Finland, the producer of radioactive waste is responsible for the handing and management of the waste as well as for the financing of these operations. This responsibility includes the final disposal of the waste. In this respect, no governmental disposal organization is foreseen.

The majority of the low- and intermediate-ievel wastes in Finland originate from the four operating nuclear power plant units. Imatra Power Company (IV0) operates two 440-MWe PWR units at the Lovi isa Nuclear Power Station and the Industrial Power Company Ltd. (TV0) operates two 660-MWe BWR units at the 0lkiluoto Nuclear Power Station. Only a minor amount of low- and intermediatelevel wastes originate from other sources such as research laboratories, hospitals and industry.

A1) reactor waste from the operation of the power plants is treated at the power plant sites. In Loviisa, the liquid waste is stored in large tank storage facilities pending the construction of a solidification facility based on the cementation process. Approximately $300 \mathrm{~m}^{3}$ of evaporator concentrates, $28 \mathrm{~m}^{3}$ of spent ion exchange resins and $200 \mathrm{~m}^{3}$ of dry compacted waste has been kept in storage during the nine operational reactor years for the two BWR power production units in Loviisa. The Loviisa Nuclear Power Station has a tank storage facility with eight tanks of $300 \mathrm{~m}^{3}$ each. With the current 1 ow accumulation rate of wet waste, the onsite capacity of the storage will be sufficient till the late 1980s at which time a solidification process is expected.

(a) Dr. A. K. Muurinen, Technical Research Centre of Finland, Reactor Laboratory, Otakaari 3A, 8, SF-02150 Espoo 15, Fintand (private communications). 
During the six operational reactor years at the two 01kiluoto BWR reactors, approximately $260 \mathrm{~m}^{3}$ of bitumenized wet wastes and $220 \mathrm{~m}^{3}$ of dry waste has been accumulated.

The bitumenization of wet wastes at the 01 kiluoto Nuclear Power Station is based on a batch process which dries the waste slurry and subsequently incorporates it into hot bitumen. Bitumenized waste at the 01 kiluoto station is poured into 200-l drums and transferred to specified storage rooms of the waste buildings. Preliminary design of a new interim storage facility has been started since the existing storage facilities will be filled by 1985 .

At the 01kiluoto Nuclear Power Station a separate storage facility has been constructed for compressible wastes. This facility has a capacity for five thousand 200-l drums. The facility is designed for waste drums with a maximum surface dose rate of $0.75 \mathrm{mSr} / \mathrm{h}$. Compressible low-level waste is compacted into 200- 2 drums at both power plants. Economical evaluations have not given any incentives for the development of incineration of combustible waste in Finland.

Shallow-land disposal of radioactive waste is considered impractical in Finland because the soil layers covering the bedrock are generally very thin. The most feasible alternative is disposal of an underground repository excavated in the bedrock. Primary considerations is being given to the suitability of the bedrock at the power plant sites for the final disposal of reactor wastes. According to present plans, the repositories would be operational in 1992.

The Radiation Protection Institute maintains a storage facility for nonpower plant wastes. The volume accumulated since the year 1974 amounts to about $30 \mathrm{~m}^{3}$.

The two power companies operating nuclear power plants have established a joint organization, the Nuclear Waste Commission of Finnish Power Companies, to plan and coordinate the research and development activities in the field of radioactive waste management. 
Major emphasis in research and development are directed towards the selection and design of repositories for low- and intermediate-level wastes and the construction of a solidification plant in Loviisa.

The size of the economy in Finland limits the ability to allocate resources to the waste management $R \& D$ work. Therefore, Finland participates in various cooperative nuclear R\&D activities with the Nordic countries, Sweden, Denmark, and Norway. Finland is also involved in various research activities with many of the OECD and IAEA countries.

France $(5,11,48-53)$ has an active nuclear energy program (43 operating reactors) and is a producer of nuclear weapons. All possible activities in the nuclear cycle are conducted within France's continental borders, giving rise to the production of varied types and considerable amounts of low- and intermediate-level wastes. These activities include mining and milling, uranium enrichment, fuel fabrication and fuel reprocessing, as well as research and development.

The French Atomic Energy Commission (Commissariat à L'Énergie Atomique, CEA), operating under the direct authority of the Ministry of Industry and Research, is responsible for controlling all nuclear activities from research to defense. In 1979 the National Agency for the Management of Radioactive Wastes (ANDRA) was created as an agency within the CEA. It is this agency which is responsible for long-term management of radioactive wastes, including treatment, transportation, storage and final disposal; funding is provided by the waste producers. The Institute for Nuclear Protection and Safety (ISPN), another branch of the CEA, has, as one of its responsibilities, the assessment of waste management plans and of new waste treatment processes.

Currently, the generation of low-level beta-gamma wastes which contain insignificant levels of alpha-emitters amounts to approximately $25,000 \mathrm{~m}^{3}$ per year. It is estimated that this rate will increase to $70,000 \mathrm{~m}^{3}$ per year by 2000. Of the total low-level waste generated in 1982, nuclear power plants produced $38 \%$, reprocessing- $-38 \%$, large research 1 abs $-9 \%$, fuel production- $-10 \%$, small producers--3\% and miscelianeous- $-2 \%$. 
Low-ievel liquid wastes are first treated by evaporation or chemical precipitation. At many nuclear power plants in France sludges and concentrates are conditioned with cement. The research centers of Marcoule, Saclay, Valduc and Cadarache use bitumen as a solidification agent. At one power plant, thermosetting plastic is used. Solid wastes are treated by volume reduction where possible and procedures such as grinding, compaction and incineration are used. Prior to final disposal certain wastes packaged in $100-\ell$ or $200-\ell$ drums are compacted and placed into concrete shells with poured cement coverings. Wastes from small institutional users are collected, sorted and treated appropriately according to waste type.

Most wastes received at the ANDRA central treatment facilities are packaged in 100 or $200-\imath$ drums while other wastes are packaged in $5 \mathrm{~m}^{3}$ steel liners. Processed wastes are emplaced in concrete containers the walls of which are 10,20 and $30 \mathrm{~cm}$ thick depending on activity levels.

A central facility for the disposal of low- and intermediate-level wastes containing low-levels of alpha-emitters is located near the fuel reprocessing center at La Hague. This center, Centre de la Manche, is a shallow-land disposal site which has been operating since 1969. Disposal at this site may be in underground vaults or in tumuli. Vaults are constructed underground of concrete; compacted wastes fixed in cement are placed in the vaults which are then filled with concrete to create a monolithic structure. On top of that a tumulus is constructed by arranging lower activity waste packages and then covering them with earth and clay materials in designed layers. More than $150,000 \mathrm{~m}^{3}$ of waste have been disposed of at Centre de la Manche. Investigations are under way which will lend to the selection of one or more disposal sites to replace the existing disposal site when it is filled by the end of this decade.

Certain wastes which have activities that preclude their disposal as lowlevel waste are stored by the producer at their site. In some cases this type of waste is temporarily stored by ANDRA in ditches or wells. 
The Federal Republic of Germany (FRG) $(33,52,54-57)(a, b)$ has an active nuclear power program and is involved directly in all steps of the nuclear cycle except mining, milling, and enrichment. The FRG has thirteen operating power reactors, fabricates both $L W R$ and MOX fuels at several facilities, reprocesses spent fuel at Karlsruhe, and supports major R\&D centers at Karlsruhe and Jülich. These activities along with institutional and industrial uses of radioisotopes are the sources of low-level radioactive wastes in the FRG.

The federal government coordinates the FRG nuclear programs; sponsors fuel cycle and waste management R\&D; and is charged by law to design, build, and operate any radioactive waste disposal facilities. The privately owned utilities are responsible for the fuel cycle, including spent fuel storage, reprocessing and/or disposal and/or treatment of the associated wastes. The nuclear utilities are also to pay the cost of waste disposal by the government. BMFT, the Federal Ministry for Research and Technology provides overall program coordination and sponsorship of R\&D; BMI, the Ministry of the Interior supervises licensing procedures. The utilities and industrial firms handle lowlevel waste management, except disposal. PTB, the Federal Physical-Technical Institute, is a government agency for designing, licensing, and operating waste repositories, the only disposal means practiced in the FRG.

There is no official definition of low-level wastes existent in the Federal Republic of Germany. However, low-level waste is understood to include conditioned waste not exceeding the specific activities as specified for LSA in the IAEA Regulations for the Safe Transport of Radioactive Materials, and a dose rate which does not exceed $200 \mathrm{mrem} / \mathrm{hr}(2 \mathrm{mSv} / \mathrm{h})$ on the external face of the transport container and $10 \mathrm{mrem} / \mathrm{h}(0.1 \mathrm{mSv} / \mathrm{h})$ at 1 meter distance from the external face of the transport container.

It is estimated that by the year 2000, the radioactive waste generated in the entire range of nuclear power applications (nuclear power plants, industry, research, medicine, etc.) will amount to 250,000 to 500,000 drums $(400 \ell)$ of

(a) Dr. Ernst Warnecke, Physikalisch-Technische Bundesanstalt, Postfach 3345, D-330 Braunschweig, Federal Republic of Germany (private communications).

(b) Dr. Helmut Krause, Kernforschungszentrum Karlsruhe $\mathrm{GmbH}$, Postfach 3640 , D-7500 Karlsruhe, Federal Republic of Germany (private communications). 
LLW and 70,000 to 100,000 drums $(400 \ell)$ of MLW. Approximately $50 \%$ of these wastes will result from the operation of nuclear power plants.

Various techniques for treating low- and intermediate-level wastes have been under development and in use for several years. These have included systems for decontamination of liquid wastes, volume reduction of combustible and noncombustible wastes, and immobilization processes. Incinerator plants for low-level wastes are in operation at the Karlsruhe and Jülich nuclear research centers. Karlsruhe also has a cutting facility and compaction station.

Presently, most aqueous and other wastes are solidified and/or fixed with hydraulic cement. Bituminization had been used at KfK for several years, however, it is not practiced for the time being due to licensing problems connected with onsite storage of the packaged waste.

At the Karlsruhe Nuclear Research Center (KfK), radioactive waste solutions are mixed with cement in the waste drums using a planetary paddle stirrer. An average number of 2,000 drums containing conditioned waste are produced every year.

At the Jülich Nuclear Research Establishment (KFA), the waste solutions are first concentrated in a drum drier. The product of the drum drier is mixed by a planetary paddle stirrer with neat cement in the drum. In 1981, approximately 20 metric tons of drum drier product was processed by this technique.

Transnuklear (TN) uses mobile systems for conditioning radioactive wastes at the place of origin, e.g., in nuclear power plants. At the MOWA facility, the liquid wastes are mixed with cement in the drum using a stirrer.

A different technique is applied by Gesellschaft für Nuklear-service (GNS). In a mobile facility called FAFNIR, a tumbling mixer is used to condition liquid originating in nuclear power operations. With this method, mixing with cement does not take place in the waste drums but in continuous mixers.

The present concept for storage and disposal of low-level (LLW) and medium-level (MLW) wastes in the Federal Republic of Germany provides for most of the low- and intermediate-level wastes produced in the FRG to be packaged in 
painted sheet metal drums of 200-l or 400- $\ell$ drum volume. The LLW/MLW derived from nuclear power plants will be stored in the nuclear power station storage facilities (capacities amounting up to 9,000 drums each) or in 2 central interim waste storage facilities at Gorleben and Mitterteich (capacities up to 40,000 drums each) which began operation in 1984 .

Nuclear waste from research centers, industrial and medical facilities and from fuel cycle plants will be stored either at intermediate storage facilities operated under the States' responsibility or at engineered storage facilities at research centers.

The FRG waste disposal policy necessitates the disposal of all types of radioactive waste in deep geological formations.

In 1982, investigations regarding the suitability of the former Konrad iron-ore mine as a final repository were terminated. Based on the results of these investigations, the licensing procedure, required by the German Atomic Energy Act, was started in August 1982. According to the present time schedule, startup of active operation in the Konrad repository is foreseen for 1988 for the disposal of low-level and decommissioning waste.

In the Asse salt mine, research and development activities of the GSF are concentrated on the disposal of medium-level or heat producing waste. A decision with respect to the use of the mine as a repository will be made by the Federal Government by the end of 1983. Long-lived waste from reprocessing and possibly conditioned fuel elements will be the bulk of the waste destined for the salt repository in the Gorleben sait dome.

India $(58-60)(a)$ though not considered an industrialized country, has an ambitious nuclear program. They have five operating power reactors and have demonstrated the capability to make weapons material. The government of India, through the Department of Atomic Energy (DAE), is responsible for all nuclear fuel cycle operations including the management of radioactive wastes. DAE is empowered to make and promulgate rules and regulations regarding licensing of nuclear facilities, requirements for radiation surveillance, inspection of

(a) Dr. K. Balu, Head, Waste Management Division, Bhabha Atomic Research Centre, Rombay, Trombay 400085 , India (private communications). 
facilities, enforcement of regulatory requirements, etc. Nuclear research and development is performed primarily by the Bhabha Atomic Energy Centre (BARC) at the Trombay site.

In India, low-level radioactive waste is defined as liquid waste containing up to $0.1 \mathrm{mCl} / \mathrm{e}$ of radioactivity and solid waste having a contact dose of not more than $200 \mathrm{mR} / \mathrm{hr}$. Low-level wastes are currently being generated at the Tarapur Atomic Power Station (TAPS), which consists of two BWR units each of 190 MWe, the Rajasthan Atomic Power Station (RAPS) which consists of two PHWR units each of 220 MWe generating capacity, and fuel cycle support activities, including three fuel reprocessing facilities, uranium refinery and fuel fabrication plants, and isotope production facilities. The estimated volumes of waste arising from the four nuclear power plants include $1,700 \mathrm{~m}^{3}$ solid waste, $2,500 \mathrm{~m}^{3}$ low-level waste concentrates and $650 \mathrm{~m}^{3}$ of treated intermediate-level wastes. For a projected power production of 10,000 Mwe by year 2000 an estimated $107,000 \mathrm{~m}^{3}$ of solid wastes, $77,100 \mathrm{~m}^{3}$ of $10 \mathrm{w}-1$ evel waste concentrates and $19,900 \mathrm{~m}^{3}$ of intermediate-level waste will be produced.

Unlike many countries where the repositories receive only conditioned waste, the shallow ground repositories in India receive unconditioned wastes and are provided with equipment to treat liquid waste concentrates, spent ion exchange resins and other solid waste concentrates. Incineration of combustible solid wastes and compaction of compressible wastes have also been in use at the sites of the shallow ground repositories.

Low-level liquid wastes are treated to remove activity by chemical treatment, ion exchange or by evaporation. The treated effluents are discharged in accordance with regulations while the sludges containing most of the radioactivity are filtered and solidified. Steam evaporation is used for concentration of liquid wastes having relatively higher specific activity. Liquid radioactive wastes are also concentrated at ambient temperatures by solar evaporation. The solid contents are solidified in suitable matrices. In general, cement is used as the matrix for incorporation of low activity concentrates. Bitumen is used for incorporation of waste concentrates from evaporation of liquids with intermediate levels of activity. More recently, polymer matrices are being used for immobilization of spent ion exchange resins 
and higher active waste concentrates. Solid wastes are compacted or incinerated prior to disposal. Incinerator ash is immobilized in cement. Treated liquid effluents are discharged to the ocean within limits at coastal locations such as Tarapur and Kalpakkam, near Madras.

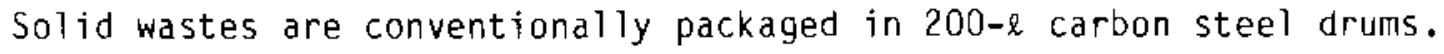
Plastic bags are used for suspect or very low activity waste. Low- and intermediate-level wastes are not stored for extended periods prior to treatment and disposal.

The major mode of disposal for low- and higher-activity solid wastes has been engineered facilities in shallow 1and. In general, the three types of disposal modes which have been used are:

1. Unlined earth excavation (utilized only for wastes with suspect contamination)

2. Reinforced cement concrete trenches

3. Steel-iined concrete "tile-holes."

The selection of the disposal mode is based upon site conditions. The wastes stored in near surface concrete vaults and tile-holes are considered retrievable.

The earliest near-surface storage and disposal facility constructed was the Radioactive Solid Storage site at the BARC site in Trombay. This has been in operation for about 20 years. The disposal facility located at Tarapur has been in operation for the past 10 years. Recently, sites have been operating at Rajasthan and Madras while other shallow-land repositories are currently being developed at Hyderabad and Narora. It appears that shallow-land repositories are being located at each of the sites where nuclear installations have been set up.

italy, $(52,61,62)$ though an early entrant in the nuclear energy field, has been unable to develop a significant nuclear energy generating capacity because of political uncertainties. Nevertheless, they have three operating power reactors, fuel fabrication facilities, two pilot-scale reprocessing facilities, and three nuclear research centers. 
Treatment of low-level wastes varies from producer to producer. At reactors, concentration and storage in tanks is a common practice. Fixation in urea formaldehyde is employed at the Caorso site but is unlikely to be adopted in any future applications. Cementation has been tested at two sites and is foreseen as the best choice for future installations. The only treatment used for solid wastes is compaction of compressible wastes. Packaging in drums is cominonly used.

Low-level liquid wastes at the reprocessing sites are concentrated and stored onsite in tanks; both plastic and cement are being evaluated for fixation of these wastes. Low-level solid wastes are packaged in drums without treatment. At the ITREC reprocessing facility, low-level wastes are disposed to surface trenches; at the EUREX reprocessing facility, such wastes are placed in drums and stored.

Low-level liquid wastes originating from the various research centers are either concentrated or decontaminated by chemical treatment, followed by fixation in either cement or bitumen. Organic wastes are burned or adsorbed on an inert material. More than $2000 \mathrm{~m}^{3}$ of solid or solidified wastes have been accumulated at the research centers.

Italy has not yet selected a means for final disposal of radioactive wastes. A small amount of low-level waste was dumped into the Atlantic in 1969 under $\mathrm{NEA}^{(a)}$ surveillance. Although not used since then, sea dumping is still considered a potential disposal means. Shallow-land burial is used at the CEC (b) -Ispra Center and the ITREC reprocessing facility. Otherwise, all wastes are being packaged and stored on the producing site. Late in 1982, a new public company, NUCLECO, was assigned the responsibility to develop methods for collecting, treating, and disposing of non-HLW radioactive wastes which originate from hospitals, universities, research centers, and nuclear power stations. Under guidance from ENEA, (c) it also researches deep sea disposal of radioactive waste. This service company is also active in dismantling nuclear facilities and in decontamination.

(a) NEA - OECD Nuclear Energy Agency.

(b) CEC - Commission of the European Communities.

(c) ENEA - Corporation for Nuclear Energy and Alternative Energy. 
Japan, $(6,63-65)(a, b)$ a highly industrialized country with no indigenous energy sources, has an aggressive program for developing nuclear power. Presently 28 power reactors are operating; supporting activities include fuel fabrication and reprocessing.

The government funds most of the nuclear R\&D, including fuel cycle and waste management programs, and is responsible for disposal of high-level waste. Industry is responsible for the commercial fuel cycle, for developing technology (with government help) and industrial capability for disposal of LLW, and is to pay for HLW disposal on the basis of the principle that "the polluter pays."

Several government agencies and private companies have major fuel cycle and waste management responsibilities. The Nuclear Safety Commission, in particular through its Special Committee on Safety of Radioactive Waste, is responsible for the regulation of radioactive waste. The Atomic Energy Commission of Japan sets overall guidelines regarding radioactive waste management. Research and development is performed by two groups--Power Reactor and Nuclear Fuel Development Corporation for the fuel cycle and Japan Atomic Energy Research Institute for safety. Both groups report to the Prime Minister through the Science and Technology Agency. Management of low-level wastes is now coordinated by the Radioactive Waste Management Center (RWMC), a consortion established by the electric power industries, certain nuclear industries and research institutions to coordinate industrial low-level waste management and to implement centralized processing and disposal. Radioisotopes utilized in medicine are regulated by the Ministry of Health and Welfare which is preparing its own system of radioactive waste collection.

(a) Dr. Takehiko Ishihara, Managing Director, Radioactive Waste Management Center, Mori Bldg., No. 15, Toranomon 2-8-10, Minato-ku, Tokyo, 105 Japan (private communications).

(b) Dr. Akihiko Ito, Division of Environmental Safety Research, Japan Atomic Energy Research Institute, Tokai Research Establishment, Tokai-mura, Naka-gun, Ibaraki-ken, Japan (private communications). 
At the Japanese Atomic Energy Research Institute, radioactive solid waste with a surface dose rate of $0.2 \mathrm{R} / \mathrm{hr}$ is regarded as low-level. Intermediatelevel wastes are part of the low-level waste category and include soild wastes with dose rates greater than $0.05 \mathrm{R} / \mathrm{hr}$ and less than $0.2 \mathrm{R} / \mathrm{hr}$.

Low-level wastes are mainly produced by the 28 operating power reactors which have a total generating capacity of approximately 19,000 MWe. Other producers include 4 uranium fuel fabrication facilities, a fuel reprocessing operation and a pilot-plant for uranium enrichment. There are also several large laboratories and about 1300 facilities, such as universities and hospitals, which produce low-level wastes.

In 1981 a total of $14,620 \mathrm{~m}^{3}$ of solid low-level waste was produced, processed and stored. Power reactors generated $75 \%$ of this waste and the rate of waste production is expected to increase sharply as the nuclear electric generation capacity increases to about 31,000 MWe in 1990. Fuel reprocessing activities account for approximately $20 \%$ of low-level waste.

Waste treatment in Japan is centralized for many smail institutional producers and laboratories while each nuclear power station treats its own waste. Liquid wastes are typically subject to volume reduction, usually evaporation, and the concentrates are solidified in either cement or bitumen. New processes developed by industry with funds from the Japanese government evaporate waste to a dry state and then solidify the residue in thermosetting resins.

Solid wastes are treated by compaction or incineration and are then solidified with cement, bitumen or thermosetting plastics. The long-term storage of waste, necessary until a disposal option becomes available, is adding incentive to increase the use of volume-reduction techniques.

Most wastes are packaged in 200-l steel drums and those that are not, e.g., contaminated equipment, are reported in the equivalent number of $200-\ell$ drums. All treated low-level waste is being placed in storage until a final decision has been reached regarding disposal options. There are currently over 300,000 drums being stored by utilities at their sites and there is space for 
about 200,000 more. At least another 100,000 drums are stored by other producers, particularly government facilities. By 1990 it is expected to have $1.1 \times 10^{6}$ drums of low-level waste in storage.

Japan had used ocean dumping for the disposal of small amounts of lowlevel radioactive waste and had considered reinstituting ocean dumping on a larger scale as late as 1982. Responding to pressure from neighboring countries, they have elected not to use ocean dumping. Instead, an engineered terminal storage facility is to be built at Rokkashomura in northern Japan. Operation is expected around 1991. A private company, Japan Nuclear Fuel industries Company, Inc. (JNFI), has been formed to operate the facility. The low-level radioactive storage facility will include an interim storage area, inspection and management building, the storage facility and support facilities. The new firm, backed by several electric utilities and industrial firms, will also build and operate an enrichment plant at the site.

The Republic of Korea's $(66,67)(a, b)$ rapid industrial growth over the last 20 years has led to ambitious nuclear plans. The first comercial nuclear power plant, Kori \#1, began operation in 1978. Two others, another PWR and a heavy water unit, have been added since then. The long-term plan for nuclear power plant establishment shows that Korea will have approximately a total generating capacity of 11,200 Mwe by the year 2000 .

The responsibility for nuclear energy development belongs to the Atomic Energy Bureau and the Atomic Energy Commission. Although the Korean Utility Company, government authorities and research organizations have been involved in waste management problems for the past several years, an organization for radwaste management will be established in accordance with a radwaste management policy which is to have been made by the end of 1983 . Currently, a "Committee of Radioactive Waste Management" has been organized under the Atomic Energy Commission for the purpose of finalizing a Master PIan for Radwaste

(a) Dr. Yong-Kyu Lim, Commissioner, Atomic Energy Commission, Republic of Korea, Seoul 110, Korea (private communications).

(b) Dr. Hun-Hwee Park, Head, Radioactive Waste Treatment Division, Nuclear Fuel Cycle Development, Daeduk Engineering Center, Korea Advanced Energy Research Institute, P.0. Box 7, Daeduk-Danji, Choongnam, Korea (private communications). 
Management in Korea. The plan was formulated by a task team of Korea Advanced Energy Research Institute (KAERI), and implementation was scheduled for eariy 1984 under the Ministry of Science and Technology of the Atomic Energy Commission. Fuel cycle R\&D is done by KAERI in Seoul, and the Daeduk Engineering Center, in Choongnam. All nuclear power plants are owned and operated by the Korea Electric Power Company (KEPCO).

There is no official definition of low-level waste in the Republic of Korea. The term low-level waste is used to include all wastes produced at hospitals, institutes and nuclear power plants under conditions of normal operations.

The expected accumulation of radwaste by the year 2007 is approximately 900,000 drums or $200,000 \mathrm{~m}^{3}$. Other sources of radwaste are the Triga Mark II (1962) experimental reactor at KAERI, and medical and industrial facilities. Seven nuclear power plants will be operational by 1987 .

Liquid wastes are treated by evaporation, filtration, ion-exchange and reverse osmosis. The wastes arising at nuclear power plants are solidified in cement. Wastes at the research center (KAERI) is solidified in bitumen. Solid wastes are treated by compaction and incineration. Wastes are solidified or compacted in 200-l carbon steel drums. A11 waste is in interim storage on the site of the nuclear power plant, awaiting a disposal method. The life expectancy of a carbon steel drum surface treated with zinc primer and yellow paint has been estimated at 11 years in dry storage.

Shallow-land burial has been selected as the most economical and feasible disposal option. Disposal operations are scheduled to begin in 1987 under the responsibility of a nonprofit agency, the Korea Radwaste Disposal Agency (KORDA). KORDA's prime responsibility will be transportation (from power plants to the disposal site), waste disposal including trench construction and environmental surveillance.

The Netherlands $(52,68,69)(a)$ has two operating power reactors, one a 50-MWe BWR and the other a 445-MWe PWR which satisfy 5-7\% of electrical needs.

(a) Dr. B. Verkerk, Coordinator, Nuclear Waste Programs, Netherlands Energy Research Foundation (ECN), P.0. Box 1, NL-1755 ZG Petten (N.H.) The Netherlands (private communications). 
In addition, the Netherlands supports the Petten Research Establishment, which is responsible, not only for research, but for disposal of all low- and intermediate-level wastes from reactors, hospitals, laboratories, etc. The facilities at Petten include a decontamination station and storage for several years.

The Ministry of Economic Affairs, Ministry of Public Health and Environmental Control, and the Ministry of Social Affairs have overall responsibility for nuclear energy matters. However, all decisions of the central government ministries are subject to approval by Parliment. Until recently, the government organization called the ECN-Stichting Energieonderzoek Centrum Nederland (Netherlands Energy Research Foundation), at Petten, was responsible for the collection and conditioning of all wastes for sea disposal. In 1982, when sea disposal of low-level waste was abandoned by the Dutch government, a new organization called CovRA-Centrale Organisatie Voor Radioactif Afvai, was established having the responsibility to collect, treat and store radioactive wastes produced in the Netherlands. ECN is expected to transfer its duties to COVRA.

Most of the radioactive waste is generated from the 50-MWe BWR and the 445-MWe PWR. Although the Dutch government approved plans for three new 1000-MWe nuclear plants in 1975, public opposition has delayed any further growth of the nuclear indusry in the Netherlands. The total amount of low- and medium-level radioactive waste disposed between 1965-1981, was 17,035 metric tons. In 1982, 1143 tons of packaged solids (LLW) and 1269 tons of conditioned waste (ILW), such as sludges and resins from power stations were accumulated. Annually approximately $25 \mathrm{~m}^{3}$ of very low-level organic liquids from various laboratories as well as $50 \mathrm{~m}^{3}$ aqueous liquids and some uranium contaminated solid materials from the Almelo uranium enrichment plant are collected and conditioned for disposal.

Liquid wastes at ECN are either treated in the flocculation plant or centrifuged to reduce activity below effluent levels prescribed in their license. This effluent is discharged into the North Sea via a $3 \mathrm{~km}$ long pipeline. Presently, solid wastes are compacted and packaged in concrete. However, in view 
of the policy change (sea dumping), consideration is being given to incineration of combustible materials. Intermediate-level wastes produced at the power stations are treated at the plants and conditioned either by incorporation in concrete or in self-hardening resins.

At present, all low-level solid waste is reduced in volume with a $1500-$ tonne hydraulic press and placed in 200-l drums with a concrete lining. Intermediate-level wastes, consisting mainly of solidified sludges and resins from power plants, are placed in 200-l drums with a $20 \mathrm{~cm}$-thick concrete shielding (Swiss B-containers). Interim-storage prior to disposal is in an enclosed storage facility for the $200-\ell$ drums and open air storage for the larger concrete containers.

From 1965-1982, low- and intermediate-level wastes were disposed at sea. At present, the waste is being stored awaiting decisions by the government. In the spring of 1983, a committee created by the government for the purpose of investigating alternatives to sea disposal reported on alternatives such as shallow-land burial, storage in bunkers and disposal of salt formations. The latter alternative was favored. Though the duration of the interim-storage at the Petten site was strictly limited by the local government that issued the license, it may still take some time before the government will decide upon a final disposal method.

Pakistan $^{(a)}$ operates a 125-MWe PHWR and the supporting fuel fabrication facilities. All matters pertaining to nuclear energy are organized and regulated by the Pakistan Atomic Energy Commission.

In Pakistan, low-level radioactive waste is defined in the following ways. Solid low-level waste is that waste which has a dose rate of less than $25 \mathrm{mR} / \mathrm{hr}$ beta-gamma at $50 \mathrm{~cm}$ from the center of the package. Liquid wastes containing less than $10^{-5} \mu \mathrm{Cj} / \mathrm{me}$ are regarded as low-level wastes. Most low-level waste in Pakistan is generated by their 125-Mwe CANDU-type reactor. Other low-level wastes are generated at the Pakistan Institute of Science and Technology. Lowlevel radioactive waste is not treated in Pakistan.

(a) Dr. Munir Ahmed Khan, Chairman, Pakistan Atomic Energy Commission, Islamabad, Pakistan (private communications). 
Liquid wastes are disposed into seepage pits or are diluted and pumped into the ocean. Solid wastes are subject to shallow-land burial or are disposed of in concrete-lined trenches.

South Africa $(70)(a)$ has one 920-MWe PWR operating and is readying another for operation at the Koeberg Station near Capetown. Their fuel cycle activities include uranium production and enrichment but no fuel fabrication or reprocessing.

Nuclear matters are handled for the government by the Ministry of Mineral and Energy Affairs, operating through the Atomic Energy Corporation of South Africa. The Atomic Energy Corporation consists of three principal components located at the South Africa nuclear complex at Palindaba near Pretoria. These organizations consist of: 1) the Atomic Energy Board, responsible for regulating and Iicensing: 2) the Nuclear Development Corporation of South Africa (NUCOR), responsible for research and development, and for the treatment and disposal of all radioactive wastes; and 3) the Uranium Enrichment Corporation of South Africa (UKOR).

Radioactive wastes are classified in the following manner. Trade wastes are liquids which contain the maximum normal background activity of $0.1 \mathrm{pCi} / \mathrm{ml}$; low-activity waste has a maximum activity of $100 \mathrm{pCi} / \mathrm{m}$; medium-activity waste has activity levels between $100 \mathrm{pCi} / \mathrm{ml}$ and $10,000 \mathrm{pCi} / \mathrm{ml}$; and wastes having $>10,000 \mathrm{pCi} / \mathrm{ml}$ are considered to be high-activity waste.

The Chemical Operations Department of NUCOR is responsible for the treatment of all radioactive waste. The treatment facilities are located in the Waste Treatment Plant at Pelindaba. Liquid wastes are decontaminated by a combination of chemical precipitation, evaporation, ion-exchange treatment and reverse osmosis. The concentrates from the evaporators are solidified in a cement-vermiculite mixture by means of the "vacuum intrusion" method.

Solid wastes are segregated into classes of materials in such a way that all constituents of any batch can be dealt with in the same manner. The wastes

(a) Dr. H. J. Van der Westhuizen, Manager, Chemical Operations Department, Nuclear Development Corporation of South Africa (Pty) Ltd., Private Bag X256, Pretoria 0001 , Republic of South Africa (private communications). 
are further segregated into compressible and noncompressible types. Compressible wastes are pneumatically pressed and baled. Volume reduction factors of approximately four are obtained in this way.

Solidified wet solid wastes such as ion-exchange resins and evaporator bottoms originating at the power reactors will be packaged in concrete containers, whereas compacted solid waste will be contained in steel drums. Reactor wastes will be stored onsite until the nearby disposal facility becomes operational.

Waste water from Pelindaba is discharged, after treatment, into the Crocodile River in accordance with a permit issued to NUCOR by the Department of Environmental Affairs.

Solid radioactive wastes from the Waste Treatment Plant at Pelindaba are disposed at a nearby land burial site. Tubular disposal facilities, consisting of stainless steel pipes set in high-density concrete blocks in the ground are used for the disposal of radioactive sources. Approximately eight hundred drums containing solidified, incompressible and compressed waste, together with a large quantity of incompressible low-level waste, wrapped in polyethylene sheeting, have been buried in the disposal trenches.

Wastes generated at the nuclear power plants will be disposed of by shallow-land burial at the proposed National Radioactive Waste Repository situated in the Northern Cape, approximately $80 \mathrm{~km}$ Southeast of Sprinkbok. The facility will be operated by NUCOR on behalf of the State (SA government).

Research and development efforts are being concentrated on reactor waste from formulations and property evaluation and on the National Radioactive Waste Repository.

Spain $(35,52,71-74)$ has seven operating power reactors, fuel fabrication facilities, and a nuclear research center near Madrid. Nuclear activities in Spain are controlled by government through the Nuclear Energy Agency (JEN), now primarily an R\&D organization; EMPRESA, a fuel cycle services company; the Nuclear Safety Council, safety and licensing; and ENRESA, a new company formed to handle the transport and storage of spent fuel. 
The waste treatment systems initialiy furnished at the power reactors used urea-formaldehyde (UF) to fix wet wastes. The UF systems are being replaced with cement fixation systems. The nuclear research center has done limited laboratory-scale R\&D on various techniques for HLW solidification and has a pilot waste incinerator, a liquid waste treatment plant, and a facility for sorting and compacting solid wastes. For several years Spain has stored nonHLW drums in an abandoned iron mine located in the Sierra Morena. A search is being made for other repository sites, and supporting R\&D is in progress.

Sweden $(35,52,75-79)(a)$ has seven BWRs and three PWRs operating, producing about $40 \%$ of the country's electricity, while two BWRs are under construction. Other than the fabrication of nuclear fuels and the management of radioactive wastes, Sweden relies on other countries for fuel cycle support services.

According to the Swedish Atomic Energy Law, the nuclear power utilities have the full responsibility for treatment, intermediate storage, transportation and final storage of all radioactive wastes produced at their facilities. Waste treatment and intermediate storage are taken care of by the utilities directly while transportation and final storage are handled through their daughter company, the Swedish Nuclear Fuel Supply Company (SKBF). As the operational organization, SKBF carries out research and development work, plans and constructs facilities, and supplies the government agencies with plans and figures in accordance with the legislation.

There are two regulatory authorities responsible for ensuring and promoting safety in all waste management activities. The National Institute for Radiation Protection (SSI) stipulates limits for discharges into air and water, dose limits for employers and public, and formulates, in collaboration with the utilities, suitable procedures for carrying out the work in a safe and acceptable manner. The Swedish Nuclear Power Inspectorate (SKI) stipulates safety requirements for equipment, facilities and operations. The SKI also has the responsibility to prepare licensing matters for the government (licenses are granted by the government).

(a) Mr. Sjöblom, R. Studsvik Energitechnick AB, S-61l Nykoping, Sweden (private communications). 
There is no official or formal definition of low-level waste (LLW) or intermediate-level waste (ILW) in Sweden. The terms are used in practice in the following way. Low-level waste requires no external shielding neither for transportation nor for intermediate storage. Intermediate-level waste requires shielding during transportation and intermediate storage.

In the Swedish nuclear power program, reactor construction is limited, by law, to twelve units. The twelve nuclear power reactors, consisting of 9 BWRs and 3 PWRs will, according to the Swedish program, be in operation until the year 2010 and will have produced approximately $100,000 \mathrm{~m}^{3}$ of $10 \mathrm{w}$ and intermediate-level radioactive waste from operations and about $150,000 \mathrm{~m}^{3}$ from their decomissioning. No low- and intermediate-level wastes produced in reprocessing fuel used in the reactors have been returned to Sweden. The approximate annual production of low- and intermediate-level radioactive waste from a BWR is $350 \mathrm{~m}^{3} / \mathrm{yr}$. In the PWR, less spent ion-exchange resin is produced. Instead, spent filter cartridges appear in the waste stream (about 500 per PWR/yr).

Low-level solid waste is collected at the power plants and sorted into two categories, combustible and noncombustible. Most of the combustible wastes are sent to Studsvik for incineration. The solid noncombustible waste is compacted at the power plants and packaged in drums or boxes.

Spent ion-exchange resins, filter sludges and evaporator concentrates constitute most of the wet wastes produced in Sweden. Spent ion-exchange resins from the reactor water cleanup system and powder resins from pool water cleanup systems dominate, containing more than $95 \%$ of the total activity of wet wastes.

Two different techniques are currently used in Sweden for the solidification of resins and sludges. At the Oskarshamn and Ringhals power stations some of the spent ion-exchange resins and filter sludges are solidified into concrete. At the Barsebock and Forsmark power plants the waste is solidified into bitumen.

Most of the treated or conditioned wastes have been packaged into $200-\ell$ steel drums. Reinforced concrete boxes, having an inner volume of $1 \mathrm{~m}^{3}$ are also being used to contain spent ion exchange resins and filter sludges in 
concrete. Low-level powder resins, filter sludges and other wastes are not solidified. Instead, they are carefully dewatered in transportable concrete tanks with an inner volume of $6 \mathrm{~m}^{3}$ and are kept in an above-ground storage with shielding walls at Ringhals and in a rock cavern at Oskarshamn.

Most of the waste originating from nuclear power operations has been treated and is presently kept in intermediate storage at the nuclear power production sites and at Studsvik. It is anticipated that interim storage capacities at the generation sites will satisfy waste storage requirements unti) 1985-87.

Contaminated oils are treated by filtration and centrifugation separating the oil from active particles and water. Thereafter, the oil is burned in conventional oil-fired plants. Decontamination wastes are treated by precipitation. The siudge is then dewatered by centrifugation and stored in portable concrete tanks.

The SKBF (SFR) is currently planning a central final storage facility for $10 w$ - and intermediate-level waste from reactor operations which is scheduled to receive the first shipments of waste in 1988 . The repository is located one kilometer from the shore at the Forsmark nuclear power station, in a bedrock cavity about 50 meters below the rock surface. The repository will consist of vertical silos 60 meters in height by 30 meters in diameter lined with concrete in which the high-activity LLW will be stored. These are wastes with a surface dose rate of up to $50 \mathrm{r}$ and require remote-handling. A clay layer will be placed between the concrete liner and the bedrock as an additional barrier system. Lower-activity wastes will be disposed of in horizontal tunneis. Non-contact-handled wastes will be remote-handled by overhead cranes. Contact-handled wastes will be disposed of using regular shallow-land burial type operations in these horizontal tunnels. As all of the Swedish nuclear power plants as well as the CLAB (a central interim storage facility for spent fuel) and the SFR are situated by the sea, a sea transportation system consisting of a ship designed specially for nuclear waste transport and special transport vehicles, has been developed and was put into operation at the beginning of 1983 . 
Recently, the National Institute of Radiation Protection made a decision to consider onsite shallow-land burial of certain low-level radioactive wastes. Sea dumping is prohibited by a Swedish law, as of January 1, 1972.

Most of the laboratory RRD work is carried out at the power plants, at Studsvik, and at the technical universities in Stockholm and Gothenburg.

Special emphasis on research and development in the area of low- and intermediate-level waste centers on the impact of various types and forms of waste on SFR. In the present plans, the spent resins in final solidified form will occupy about $70 \%$ of the disposal volume of the repository. The possibility of the swelling of ion-exchange resins in bituminized waste has prompted the Swedish Nuclear Power Inspectorate (SKI) to stipulate that only limited quantities of bituminized resins be disposed in the SFR. Thus, the swelling properties of bituminized waste is being investigated as well as process modifications. At Studsvik, a process for volume reduction of spent ion-exchange resin is under development (the ATOS process). A project (AMOS) is now underway at studsvik, to improve and extend the present facilities for waste treatment and intermediate storage.

In Switzerland $(35,52,80-82)(a)$ five nuclear generating stations are in operation. Switzerland obtains fuel cycle support (fabrication, enrichment, reprocessing) from other countries so waste management emphasis is on reactor, research, and institutional wastes. Radioactive waste management in Switzerland is handled by a national cooperative organization, NAGRA, which is supported by the electric utilities and the government.

The regulatory authority in matters related to nuclear power is the HSKHauptabteilung für die Sicherbeit der Kernanlagen (Nuclear Safety Department of the Federal office of Energy). This department is responsible for establishing protection goals for waste managenent practices, issuing transportation licenses and for reviewing proposals. The regulatory authority for wastes outside the area of nuclear power is BAG-Bundesant fur Gesundheitswesen (Federal office of Health).

(a) Dr. U. Niederer, Head, Waste Management Section, Nuclear Safety Department, Federal Office of Energy, CH-5303 Wurenlingen, Switzerland (private communications). 
Low-level waste is defined pragmatically as all radioactive waste that is not high-level waste, where the latter is the highly active waste resulting from the processing of spent fuel. No numerical limits (such as activity level or actinide content) are established. Actually, the name commonly used in Switzerland for this type of waste is "low- and intermediate-level waste," and a distinction is made as to whether or not shielding is necessary to achieve a surface dose rate not exceeding $200 \mathrm{mrem} / \mathrm{hr}$.

Approximately $30 \%$ of Switzerland's electricity is presently being generated by the five LWRs with a total net capacity of about 2800 MWe. Most of the emphasis in the Swiss waste management programs is on the wastes from the back end of the nuclear fuel cycle. These consist of high-level wastes which may be returned by a foreign reprocessor, low- and intermediate-level wastes from reactor operations, and decommissioning wastes. In addition there are wastes from research, industry and medical applications.

Wastes produced at the power stations are treated onsite and at EIREidgenossisches Institut fur Reaktorforschung (Federal Institute of Reactor Research) in wurenlingen. Wastes from industry, research and medical applications are collected annually by the Federal office of Health (BAG) and sent to EIR where they are incinerated or compacted and solidified. Most of the nuclear power wastes are treated in situ at the nuclear power plants, while some of them (mainly combustible wastes) are sent to EIR where they are incinerated at a central facility. However, all of the conditioning processes are not yet fully operational, hence some of the reactor wastes are stored in unconditioned form awaiting solidification at the power plant.

The solidification methods presently used in Switzerland are as follows:

Waste Type

Evaporator concentrates and sludges

Ion exchange resins

Incinerator ashes and slags

Noncombustible (mostly metallic wastes)
Solidification Material

cement, bitumen (a)

polystyrene

cement

cement

(a) The integrated dose to bitumen is limited to 8 Mrad by HSK. 
Solidified waste is packaged into steel drums having a volume of either 100 or $200 \ell$; the latter size is more commonly used.

All nuclear power plants have an onsite interim storage facility for lowand intermediate-level waste with storage capacities from 10 to 15 years. All of the wastes from EIR and from the Federal Office of Health, as well as some of the nuclear power wastes have been, until recently, disposed of by annual sea dumpings in the North Atlantic by the EIR under surveillance by the OECD/NEA. While in the past years this practice was carried out more or less as a routine operation, difficulties due to national and international complaints have arisen this year and it was felt that a government decision was necessary. The Swiss Government eventually authorized the 1983 sea dumping, but it is uncertain whether Switzerland will continue sea dumping in the coming years in face of the moratorium agreed to at the 1983 London Sea Dumping Convention.

NAGRA is currently planning an underground repository for low- and intermediate-level waste at a depth of about $200 \mathrm{~m}$ (shallow-land burial is not considered a viable option in densely populated and rainy Switzerland). According to plans, the repository should be ready to accept waste in 1995.

In addition to the ongoing search by the nuclear power utilities to complete their onsite solidification facilities, some generic work is done at EIR and NAGRA with the aim to improve the long-term behavior of solidified wastes in storage and disposal.

Taiwan $(83,84)(a, b)$ has five operating nuclear power stations, four BWRs and one PWR, and obtains all supporting fuel cycle services from other countries. Radioactive wastes originate from these reactors, the Institute of Nuclear Energy (INER), and institutional use of radioactive materials.

The Atomic Energy Council (AEC) establishes regulations and procedures regarding the handling, collection, packaging, transportation, and storage of

(a) Dr. Chou, T. S., Deputy Director, Engineering Development and Implementation Division, Institute of Nuclear Energy Research, P.0. Box 3, Lung-Tan, Taiwan 325, Republic of China (private communications).

(b) Dr. Liu, K. Y., Director, Radwaste Administration, Atomic Energy Council, 1, Lane 41, Ho Ping East Road, Section 1, Taipei, Taiwan, 106, Republic of China (private communications). 
radioactive waste. The two branches of the AEC which enforce and carry out the functions of the AEC are the Institute of Nuclear Energy Research (INER) and the Radwaste Administration (RA). The INER is primarily concerned with research and development in support of AEC activities while the RA, instituted in 1981, has the responsibility for the safe management of radioactive waste and the protection of public health through enforcement of the AEC policy and regulations. Other organizations involved in waste management are the Ministry of Education Affairs and the Ministry of Economic Affairs under which the Taiwan Power Company (TPC) operates the government-owned nuclear power plants.

According to the Radwaste Management Ruie published by the Atomic Energy Council (AEC) of the Taiwan Republic of China, there are four different levels of solid or solidified radioactive waste, defined as follows:

(1) High-level waste

(2) Medium-level waste

(3) Low-level waste

(4) Low-low-level waste surface dose rate $>2 \mathrm{R} / \mathrm{hr}$ $2 \mathrm{R} / \mathrm{hr}>$ surface dose rate $>200 \mathrm{mR} / \mathrm{hr}$ $200 \mathrm{mR} / \mathrm{hr}>$ surface dose rate $>5 \mathrm{mR} / \mathrm{hr}$ surface dose rate $<5 \mathrm{R} / \mathrm{hr}$.

It has recently been proposed that the AEC adopt the USNRC low-level waste classification as described in 10 CFR 61.

The major sources of low-level waste are the five nuclear power units, with a total output of $4000 \mathrm{MW}$, presently in operation in Taiwan. Another unit (PWR) of $950 \mathrm{MW}$ is presently under construction. Wastes are also generated at the 40-MW Taiwan Research Reactor (TRR) and by therapeutic centers, research laboratories, universities and industrial establishments.

All of the waste produced at the nuclear power plants is treated and processed at the generation site. Wastes from the TRR and various research and industrial institutions are treated at the Institute of Nuclear Energy Research (INER). Liquid wastes are treated with ion exchange resins or concentrated and solidified with cement. Combustible solid wastes are incinerated and the ash is mixed with bitumen for solidification. Noncombustible solid wastes are mixed with bitumen and compacted for solidification.

Wastes are packaged in 200-l steel drums and are stored onsite prior to inspection and approval for transport to the National Storage Site at Lan-Yu 
(Orchid Island). Lan-Yu is located $75 \mathrm{~km}$ off the southeastern coast of Taiwan. The National Storage site was completed in April of 1982 and received its first shipment of 288 drums in May 1982. The facility consists of a series of in the ground concrete 1 ined trenches for the systematic storage of radwaste drums. After the trench is fully stored, it will be covered with concrete slabs, then covered with asphalt for water-proofing. As each trench is a retrievable storage facility, no backfilling is required.

The objective of the National Lan-Yu Storage Site is to store low-level solid or solidified radwaste before final disposal. The facility has the capacity to store all solidified waste produced in Taiwan for the next 100 years.

Taiwan has not decided upon a final disposal alternative. However, because of the hydrogeological characteristics of the land and population density, sea dumping is being considered as the most feasibie disposal alternative.

The R\&D work in Tajwan is concentrated on sea dumping of radioactive wastes and volume reduction technologies. Joint research activities in sea dumping are being carried out by INER and The Institute of Oceanography. Major activities in the area of volume reduction at INER include incineration and evaluation of thermosyphon, jacketed-kettle, and thin-film evaporators.

The United Kingdom $(7,85-90)(a, b)$ has an aggressive nuclear power and fuel cycle industry as well as a nuclear weapons program. Currently, there are 38 nuclear power plants operating in the UK; 26 gas-cooled reactors (GCR), 10 advanced gas-cooled reactors (AGR), a heavy-water moderated, light-water cooled reactor and a liquid metal fast breeder reactor (LMFBR). There are also facilities for uranium enrichment, fuel fabrication and fuel reprocessing as well as a number of laboratories generating radioactive waste.

In the United Kingdom, the Department of the Environment (DOE) is responsible for development of radioactive waste management policy and research and

(a) Mitche11, N. T., Ministry of Agriculture, Fisheries and Food, Fisheries Laboratory, Lowestoft, Suffolk, NR33 OHT (private communications).

(b) Basford, C. M., Department of the Environment, Romney House, 43 Marshan Street, London, SW 1P $3 P Y$ (private communications). 
development as well as for regulation of radioactive materials and disposal. The Radioactive Waste Management Advisory Committee (RWMAC) advises the DOE and other government bodies on radioactive waste management issues. The Ministry of Defense is responsible for waste generated in military programs. The Nuclear Installations Inspectorate (NII) of the Health and Safety Executive (which reports to DOE) is responsible for handling and use of radioactive materials, including waste management aspects, at major nuclear installations. Responsibility for implementation of storage, disposal and treatment facilities for non-heat-generating wastes belongs to the Nuclear Industry Radioactive Waste Executive (NIREX) which is composed of members of the nuclear industry and nuclear power generating boards. It is through NIREX that industry develops overall and cooperative plans for its waste management under the oversight of DOE. In the UK, ocean dumping is licensed by the Ministry of Agriculture, Fisheries and Food (MAFF) and managed by the United Kingdom Atomic Energy Authority. MAFF is also responsible for performing surveys of radioactive effiuents.

Wastes with activities of less than $10^{-5} \mu \mathrm{Ci} / \mathrm{g}$ may be discarded into the environment without any special precautions. Solid wastes with activities up to $60 \mathrm{mCi}$ (beta-gamma) per $\mathrm{m}^{3}$ and with package surface doses less than $750 \mathrm{mR} / \mathrm{hr}$ are low-level wastes suitable for shallow-land burial. Low-level wastes destined for ocean disposal must conform to IAEA activity limits. Intermediate-level wastes (ILW) are those wastes the activity levels of which preclude their disposal in the ocean. ILW contains, on average, greater than $100 \mathrm{Ci} /$ ton of beta-gamma emitters or greater quantities of alpha emitters as allowed for ocean disposal.

Power reactors are estimated to generate about $6000 \mathrm{~m}^{3} / \mathrm{yr}$ of $10 \mathrm{w}-1$ evel solid waste; fuel fabrication and reprocessing generates $20,000 \mathrm{~m}^{3} / \mathrm{yr}$; and research, medical and industrial radioisotope users generate approximately $4400 \mathrm{~m}^{3} / \mathrm{yr}$. Because of the method of disposal used for low-level liquid waste no figures for liquid wastes are available.

Intermediate-level wastes which are primarily generated during fuel reprocessing and as higher activity wastes from power plants currently total $35,000 \mathrm{~m}^{3}$. The accumulation is expected to double by the year 2000 . 
Low-level liquid wastes are either diluted until they meet acceptable activity levels for release to the environment or they are treated by such processes as ion-exchange, filtration or precipitation to reduce radionuclide concentrations prior to release.

Solid wastes of very low activity are treated by incineration where possible in order to save burial space. All nuclear power stations use small "pup" incinerators to some extent. Other facilities have larger excess-ajr type incinerators. Shredding and in-drum compaction are also used for volume reduction of solid waste.

Wastes to be dumped at sea, such as chemical sludges or solid dispersible materials, are solidified in cement. Solidification takes place by either direct encapsulation in cement waste forms or by encapsulating the waste container as a unit in another container by pouring cement mortar between the two.

It is proposed that some intermediate-level wastes such as ion exchange resins be solidified with a polymer for final disposal.

For land burial, wastes are packaged in either plastic bags or 200-2 metal drums. Waste packages to be disposed of at sea must conform to NEA and MAFF guidelines. All are drum-shaped packages and most wastes are cast into steel drums. Operational limits, such as maximum crane load, limit weight to 3 tons and radiation dose to $50 \mathrm{mrem} / \mathrm{hr}$. Ninety percent of the total weight of waste dumped is packaging and shielding.

It has been the practice in the UK to store wastes in an unprocessed form. Much of the intermediate-level wastes, which are too active for ocean disposal, are stored in tanks or vaults awaiting availability of a final disposal site.

Low-level radioactive waste is disposed of in three ways in the UK. Below a certain activity, waste is discarded into waterways or as local refuse. Slightiy higher activity wastes are disposed of by shallow-land burial at Drigg on the northwest coast. There, waste is placed in trenches which are about $25 \mathrm{~m}$ wide, $8 \mathrm{~m}$ deep and ultimately $700 \mathrm{~m}$ long with at least one meter of soil covering. The total volume of waste accumulated at Drigg is currently about $100,000 \mathrm{~m}^{3}$. 
Until 1984, much waste was discarded by ocean dumping. In 1981, 3,000 packages with a total gross weight of 2,500 tons were dumped which contained 2,000 Ci alpha, and 100,000 Ci beta-gamma activity. The London Dumping Convention agreed in 1983 to a two-year moratorium on further sea dumping. The UK, though not in favor of the moratorium, was pressured into honoring the agreement by the National Union of Seamen. Attention is now focused on landbased disposal of low-level wastes and NIREX is considering two new disposal facilities for low- and intermediate-level wastes. Shallow-land burial would be used for low-level and short-lived intermediate-level waste while a deep repository would be used for the long-lived intermediate-level wastes. Potential sites are being studied and engineering design work is under way.

A number of research projects have been undertaken to study aspects of low- and intermediate-level waste processing and disposal. Decontamination by various means is the subject of one study. Volume reduction techniques and treatment of liquids are also under investigation as is the use of various solidification agents and their suitability for varying conditions.

The United States $(3,91-98)$ having the largest number ( 83 ) of operating power reactors, a weapon material complex, and an advanced industrial base, produces more low-level radioactive waste than any other country--projected at $166,000 \mathrm{~m}^{3}$ in 1984. Of this $46 \%$ originates in defense activities, and $19 \%$ in institutional and industrial activities.

The responsibility for development and conduct of nuclear programs is shared between industry and the federal government. Power generating stations and the associated waste handling systems are built and operated by private and municipal utility groups. Similariy, industrial and medical use of radioisotopes along with the associated waste handing are the responsibility of the user. The federal government, through the U.S. Department of Energy, operates the weapon material complexes and also has total responsibility for the disposal of high-level and transuranic-contaminated wastes (>100 nCi TRU/g). Through legislation passed in 1980, the responsibility for disposal of commercially-generated low-level wastes has been given to the states; the federal government retains responsibility for disposal of low-level waste originating at federal facilities. 
In the United States, several governmental agencies exercise regulatory control over nuclear activities. Initially, all nuclear activities came under the jurisdiction of the wartime Manhattan Project. The Atomic Energy Act of 1946 established the Atomic Energy Commission as a civilian agency of the government to govern all nuclear activities and permitted, for the first time, limited civilian use by private industry. Responsibility for control of radioactive materials resided exclusively with the AEC until 1970 when the Environmental Protection Agency was created and charged with providing guidance for federal agencies in the formulation of radiation standards. Under the Energy Reorganization Act of 1974, the AEC was abolished and its energy development functions, both comercial and defense, were embodied in a new agency, the Energy Research and Developmentment Administration (ERDA). The regulatory functions over nondefense activities were placed with a new body, the Nuclear Regulatory Commission. ERDA has since been replaced by the present Department of Energy (DOE).

In the United States, low-level radioactive wastes are considered as any radioactive waste except spent fuel, high-level waste from reprocessing, and transuranic-contaminated wastes. This definition, therefore, includes the intermediate- or medium-level wastes often defined in other countries.

A new NRC regulation governing commercial LLW disposal became effective on January 16, 1983. It is directed toward protecting the public by limiting concentrations of the radionuclides present in various waste forms. There are four categories of waste based on the half-lives and concentrations of the radionuclides present: Class $A, C l a s s$, Class $C$, and wastes with concentrations greater than those for Class $C$. The NRC regulation incorporates two tables, one specifying the permissible concentrations of long-lived radionuclides and alpha-enitters and the other specifying limits for shorter-lived nuclides. Class A wastes are mostly trash, low-level resins, and biomedical wastes that do not require physical stabilization. These wastes have very low radionuclide concentrations with limited activity, and they are kept separate from higher-activity wastes. (If class A wastes are stabilized, they need not be segregated.) Class $B$ waste is largely composed of evaporator concentrates, 
filter sludges, and spent resins from nuclear power plants. These are generally of higher-activity than Class $A$ wastes and must be solidified in a stable matrix material or packaged in a high-integrity container. The Class $C$ wastes are derived from a variety of nuclear power plant, research, and industrial activities. This category includes ion-exchange resins, sealed sources, and isotope production wastes that require special means (e.g., engineered barriers) to guard against accidental intrusion after institutional controls are removed following site closure. The new regulation allows up to $100 \mathrm{nCi}$ of long-lived $\alpha$-emitters/g in Class C LLW. Wastes containing radionuclides in excess of the limits determined by the new regulation are generally not suitable for near-surface disposal. These are the "beyond $C^{\text {" }}$ waste category.

Treatments employed for low-level wastes vary from generator to generator, but generally differ little from those used in other countries. At commercial reactors, low-level liquid wastes are commonly treated by evaporation and ion exchange, with the clean liquid being recycled or released and the concentrate being fixed. Cement is the most common fixation agent; urea-formaldehyde is being discontinued, and bitumen is beginning to be adopted at some facilities. Compactors are usually employed for solid waste volume reduction at power reactors. Incinerators have not been used; however, incinerator-dryer systems have been ordered by a few utilities.

At fuel cycle supporting facilities, e.g., fuel fabrication plants, fuel reprocessing centers, research complexes, etc., chemical conditioning, evaporation, and ion exchange are commonly used to decontaminate low-level liquid wastes prior to their release to the ground or nearby waterway. The concentrate may be kept onsite or packaged (if suitably dry) for transfer to a shallow-land burial ground. At fuel fabrication plants, the concentrates are collected in lagoons for eventual recovery of the sludges and transfer to a shallow-land disposal area. Fuel reprocessing plants and associated research centers collect concentrates in tanks for handling with their high-level wastes. Low-level solid wastes are generally compacted, but incineration is not used extensively. One exception is the low-level waste incinerator recently put into operation at the Savannah River Site. 
The treatment of institutional wastes depends upon the scope of the waste operations. Large operations employ collection centers and chemical treatment, compaction and incineration. Small operations employ packaging only. Little fixation is done other than the use of drying absorbents.

In the United States, disposal by shallow-land burial is universally used. The U.S. employed sea dumping between 1946 and 1970 but has discontinued the practice. Commercially-generated and institutional wastes are presently being disposed at three commercial burial sites--Barnwe11, South Carolina, Hanford, Washington, and Beatty, Nevada. The basic operation of the three disposal sites is the same. Waste packages are placed in trenches that are 20 to 50 feet deep, 30 to 40 feet wide, and 600 feet 1ong. As a section of the trench is filled, a 2- to 6-foot cap of low-permeability soil is mounded on top of the trench. When the trench is filled, permanent markers are placed on each side of the trench. When the trench is filled, permanent markers are placed on each side of the trench that describe the contents, boundaries, and dates of use.

A public law passed by the U.S. Congress in 1980 gives each state the responsibility for disposal of commercial low-level radioactive waste generated within its boundaries. It also encourages each state to enter into a compact with other states to establish a regional disposal site. By 1984, five compacts have been introduced in congress and are awaiting approval. The activities accompanying the establishing of these compacts, along with the use of other storage/disposal methods in foreign countries, have resulted in a heightened interest in alternatives to shallow-land burial.

Low-level wastes generated during weapon material operations are disposed by shallow-land burial at the generation site; in one instance (ORNL), radioactive wastes are injected as a grout into an underlying geologic strata. 


\section{REFERENCES}

1. K. M. Harmon, L. T. Lakey, and I. W. Leigh, Summary of National and International Radioactive Waste Management Programs: 1984, PNL-5138, Pacific Northwest Laboratory, Richland, Washington, 1984.

2. L. T. Lakey and K. M. Harmon, "Management of Low-Level Radioactive Wastes Around the World," Proceedings of the Fifth Annual Participants' Information Meeting DOE Low-Level Waste Management Program, held at Denver, Colorado, August 30-September 1, CoNF-8308106, pp. 62-83, 1983.

3. U.S. Department of Energy, Spent Fuel and Radioactive Waste Inventories, Projections, and Characteristics, D0E/RW-0006, p. 145-190, 1984.

4. A. Buchnea, A. D. Ciccone, and B. Green, "The Characterization of Canada's Low Level Radioactive Wastes," Proceedings of the CNS International Conference on Radioactive Waste Management, held at Winnipeg, Canada, September 12-15, 1982, pp. 167-178, ISBN:0-919784-01-1, 1982.

5. A. Faussat, "Low Level and Intermediate Level Waste Management Practices in France," The Treatment and Handling of Radioactive Wastes, A. G. Blasewitz, J. M. Davis and M. R. Smith, eds., Battelle Press/SpringerVerlag, pp. 237-247, 1983.

6. Y. Okui, "Radioactive Waste Management Policy in Japan," Proceedings of the IAEA International Conference on Radioactive Waste Management, held at Seattle, Washington, May 16-20, 1983, IAEA-CN-43/130, Vol. 1, p. 159.

7. M. E. Ginniff, "The Siting, Design and Construction of Facilities for Low and Intermediate Level Radioactive Wastes in Great Britain," Proceedings of the IAEA International Conference on Radioactive waste Management, held at Seattie, washington, May 16-20, 1983, IAEA-CN-43/28, Vol. 3, p. 525 .

8. R. Rometsch, "Nuclear Waste Management in Switzerland." IAEA Bulletin, $24(2)$, June 1982.

9. J. R. Mernagh, P. J. Dinner, L. R. Olden and R. G. Tulk, "Implications of Pathway Analysis of de Minimis Concentrations of Radioactive Waste," The Treatment and Handling of Radioactive Wastes, A. G. Blasewitz, J. M. Davis and M. R. Smith, eds., Battelle Press/Springer-Verlag, pp. 582-586, 1983.

10. "Standardization of Radioactive Waste Categories," IAEA Technical Report Series No. $101,1970$.

11. S. C. Cohen, "A Perspective of the French Low-Level Radioactive Waste Management Program," Radioactive Exchange, 3(13), August 31, 1984. 
12. International Atomic Energy Agency, "Convention on the Prevention of Marine Pollution by Dumping of Wastes and Other Matter," The Definition Required by Annex I, paragraph 6 to the Convention, and the Recommendations Required by Annex II, Section D, INFCIRC/205/Add.17Rev.1, IAEA, Vienna, Austria, 1978.

13. N. S. Sunder Rajan, M. S. Kumra and M. K. Sinha Ray, "Research and Development Studies in the Management of Alpha-Bearing Wastes in India," Proceedings of the IAEA/CEC Symposium on the Management of AlphaContaminated wastes, held in Vienna, Austria, June 2-6, 1980 , International Atomic Energy Agency, Vienna, Austria, 1980.

14. N. J. Keen and A. G. Duncan, "A Review of Radioactive Waste Management Programmes in the United Kingdom," The Treatment and Handling of Radioactive Wastes, A. G. Blasewitz, J. M. Davis and M. R. Smith, eds., Battelle Press/Springer-Verlag, pp. 34-39, 1983.

15. 10 CFR 61, "Licensing Requirements for Land Disposal of Radioactive Waste," U.S. Federal Register, 47:248, December 27, 1982.

16. D. Richtery and S. Fareeduddin, "Developing Guidelines on Managing Radioactive Waste," IAEA Bulletin, 24(2):6-12, June 1982.

17. 0. I. Oztunali and G. W. Roles, De Minimis Waste Impacts Analysis Methodology, NUREG/CR-3585, February 1984.

18. F. H. Passant, "Low- and Intermediate-Level Waste Management Practices in the United Kingdom," The Treatment and Kandling of Radioactive Wastes, A. G. Blasewitz, J. M. Davis and M. R. Smith, eds., Battelle Press/ Springer-Verlag, pp. 256-260, 1983.

19. E. E. Purvis, III, "Nuciear Annex: Argentina/U.S. Cooperative Energy Assessment," Office of International Affairs, U.S. Department of Energy, January 1981.

20. J. A. Recalde, "Operative Experience in Radioactive Waste Treatment in Atucha Nuclear Power Plant," Proceedings of the OECD/IAEA conference on On-Site Management of Power Reactor Wastes, held at Zurich, Switzerland, March 26-30, pp. 153-167, 1979.

21. A. Migliori de Beninson and E. Palacios, "Policy on Waste Management and Its Application in Argentina," Proceedings of the International Conference on Radioactive Waste Management, held at Seattle, Washington, May 16-20, 1983, IAEA-CN-43/121, Vol. 1, p. 139.

22. P. Patek, "Treatment of Liquid Wastes at the Austrian Research Center at Seibersdorf," OEFZS. Ber No. 4126, November 1981.

23. NUKEM Market Report on the Nuclear Fuel Cycle: Special Report--Belgium, NUKEM GmbH, Hanau, FRG, July 1979. 
24. M. Frerotte, "Waste Management Policy and Its Implementation in Belgium-Recent Trends," Proceedings of the International Conference on Radioactive Waste Management, held at Seattle, Washington, May 16-20, 1983, IAEA-CN-43/122, Vo1. 1, p. 191.

25. J. C. Claes, N. Van de Voorde and P. Dejonghe, "Low- and IntermediateLevel Waste Management Practices in Belgium." The Treatment and Handling of Radioactive Waste, A. G. Blasewitz, J. M. Davis and M. R. Smith, eds., Battelle Press/Springer-Verlag, pp. 228-236, 1983.

26. P. Dejonghe, L. Baetsle, J. Claes, R. De Batist, R. Heremans and N. Van de Voorde, "General Perspectives in Radioactive Waste Management in Belgium," The Treatment and Handling of Radioactive Wastes, A. G. Blasewitz, J. M. Davis and M. R. Smith, eds., Battelle Press/SpringerVerlag, pp. 7-13, 1983.

27. P. Manfroy, "Disposal of Radioactive Wastes in a Deep Clay Formation. Construction of an Underground Laboratory for an In-Depth Experimental Program," Proceedings of the International Conference on Radioactive Waste Management, held at Seattle, Washington, May 16-20, 1983, IAEA-CN-43/54, Vol. 3, p. 275 .

28. C. Sy1lus, "Brazilian Nuciear Program--Strategy Adopted for Technology Transfer," Proceedings of the Second Pacific Basin Conference on Nuclear Power Plant Construction, Operation, and Development, held at Tokyo, Japan, September 25-29, 1978, 29:27-35, ISSN: 0003-01B4.

29. "Brazil Cuts Programme," Nuclear Engineering International, April 1982 , 27(326): 11, ISSN: 0029-5507.

30. T. E. Rummery and D. Lisle, "Radioactive Waste Management Policy and Its Implementation in Canada," Proceedings of the IAEA International Conference on Radioactive waste Management, held at Seattle, Washington, May 16-20, 1983, IAEA-CN-43/165, Vol. 1, p. 175.

31. D. H. Charlesworth, "Low- and Intermediate-Level Waste Management Practices in Canada." The Treatment and Handling of Radioactive Wastes, A. G. Blasewitz, J. M. Davis and M. R. Smith, eds., Battelle Press/SpringerVerlag, pp. 248-251.

32. D. H. Charlesworth and T. J. Carter, "Low- and Intermediate-Waste Management in Canada," Proceedings of the International Conference on Radioactive Waste Management, held at Winnipeg, Manitoba, September 12-15, 1982, pp. 242-248, ISBN 0-919784-01-1.

33. Nuclear Engineering International, May 1979, pp. 13-14.

34. G. Sitzlack, "Radioactive Waste Management Policy and Its Implementation in the German Democratic Republic," Proceedings of the IAEA International Conference on Radioactive Waste Management, held at Seattle, Washington, May 16-20, 1983, IAEA-CN-43/411, Vol. 1, p. 115. 
35. J. U. Heinonen and E. Malásek, "Disposal of Low- and Intermediate-Level Radioactive Wastes in Shallow Ground and Rock Cavities," Proceedings of the International Conference on Radioactive Waste Management, held at Seattle, Washington, May 16-20, 1983, IAEA-CN-43/143, Vol. 3, p. 125.

36. E. Malásek, E. Hladky, and L. Tomik, "Practice in Management of Radioactive Waste from Nuclear Power Plants," Proceedings of an IAEA Seminar on the Management of Radioactive Waste from Nuclear Power Plants, held at Karlsruhe, FRG, on October 5-9, 1981, IAEA-TECDOC-276, pp. 31-41.

37. Z. Diouhý, J. Korfus, E. Malásek, J. Marek, and M. Seliga, "Disposal of Low- and Intermediate-Level Waste in Czechoslovakia," Proceedings of an OECD/IAEA Symposium on the Underground Disposal of Radioactive Wastes, held at Otaniemi, Finland, July 2-6, 1979, pp. 209-219.

38. IAEA Bulletin, 21(4), 1979 .

39. D. 1. Gusey, A. S. Belitsky, A. D. Turkin, and V. M. Kozlov, "Ways of Solving the Problems of Radiation Safety and Environmental Protection in Handling Radioactive Waste at Atomic Power Stations in the USSR," Proceedings of the IAEA International Conference on Nuclear Power and Its Fuel Cycle, held at Salzburg, Austria, May 2-13, 1977.

40. E. Malásek and E. Tittlova. "Treatment of Radioactive Wastes at the Czechoslovak Nuclear Power Station." Proceedings of the OECD/IAEA Symposium on the On-Site Management of Power Reactor Wastes, held at Zurich, Switzerland, March 26-30, 1979, pp. 185-197.

41. B. Belitsky, "Removing Radioactive Rubbish in the USSR," New Scientist, 69:436-437, February 26, 1976.

42. B. Belitsky, "The Soviet Answer to Nuclear Waste," New Scientist, 74:128-129, April 21, 1977.

43. A. M. Petrosyánts, "Radioactive Waste 0isposal," Problems of Nuclear Science and Technology: The Soviet Union as a World Nuclear Power, 4th Ed., Pergamon Press, pp. 323-333, 1981.

44. A. A. Abdel-Rassoul, H. R. Higgy, and M. R. El-Sourougy, "Radioactive Waste Management in Egypt," Proceedings of the IAEA International Conference on Radioactive Waste Management, held at Seattle, Washington, May 16-20, 1983, pp. 229-248, IAEA-CN-43/3, Vol. 1, p. 229.

45. Z. Makipentti, "Waste Management Policy and Its Implementation in Finland," Proceedings of the IAEA International Conference on Radioactive Waste Management, held at Seattle, Washington, May 16-20, 1983, IAEA-CN-43/128, Vol. I, p. 167. 
46. E. H. Tusa and H. Harkonen, "Management of Low- and Intermediate-Level Reactor Waste from Finnish Nuclear Power Plants," Proceedings of the IAEA International Conference on Radioactive Waste Management, held at Seattle, Washington, May 16-20, 1983, IAEA-CN-43/94, Vol. 2, p. 147.

47. A. A. Toivola, "Treatment, Monitoring an On-Site Storage of Solid waste at the 01kiluoto BWR Nuclear Power Plant," Proceedings of the IAEA Seminar on the Management of Radioactive Waste from Nuclear Power PTants, held at Karlsruhe, FRG, October 5-9, 1981, pp. 255-256, IAEA-TECD0C-276.

48. B. De Fontreaux, F. Habib, J. M. Lavie and J. Lefevre, "The French Radioactive Waste Management Policy and Its Implementation by the National Agency for Management of Radioactive Wastes and the French Atomic Energy Commission," Proceedings of the International Conference on Radioactive Waste Management, held at Seatt1e, Washington, May 16-20, 1983, IAEA-CN-43/450, Vo1. 1, p. 101.

49. J. M. Lavie and Y. Marque, "Shallow Land Disposal of Low- and Intermediate-Activity Solid Wastes in France: 13 Years of Practical Experience," Proceedings of the International Conference on Radioactive Waste Management, held at Seattle, Washington, May 16-20, 1983, [AEA-CN-43/112, Vol. 3, p. 477.

50. H. Bastien Thiry, J. P. Laurent, and J. L. Ricoud, "Foreign Experience and Projects for the Treatment and Packaging of Radioactive Wastes from Reprocessing Facilities," Proceedings of the IAEA International Conference on Radioactive Waste Management, held at SeattTe, washington, May 16-20, 1983, IAEA-CN-43/114, Vol. 2 , p. 219.

51. Y. Sousselier, "National and Cooperative Program for Waste Management in France," The Treatment and Handling of Radioactive Wastes, A. G. Blasewitz, J. M. Davis and M. R. Smith, eds., Battelle Press/SpringerVerlag, pp. 22-26, 1983.

52. L. Mergan and M. Vandorpe, "Low Level Waste Management--A Brief Overview of the Western European Countries," The Treatment and Handling of Radioactive Waste, A. G. Blasewitz, J. M. Davis and M. R. Sinith, eds., Battelle Press/Springer-Verlag, pp. 555-558, 1982.

53. J. M. Lavie and A. Barthoux, "The Management of Low and Medium Level Waste in France," Waste Management ' 82 , Proceedings of the Symposium on Waste Management, held at Tucson, Arizona, March 8-11, 1982, 1:281-296.

54. B. Reuse, "Waste Management Policy and Its Implementation in the Federal Republic of Germany," Proceedings of the International Conference on Radioactive Waste Management, held at Seattle, Washington, May 16-20, 1983, IAFA-CN-43/12, Vol. 1, p. 149. 
55. W. W. Bähr, G. Höhlein, R. H. Kroebel, and W. Lins, "Experience and Projects for Treatment and Conditioning of all Radioactive wastes from Reprocessing Plants in the Federal Republic of Germany, "Proceedings of the IAEA International Conference on Radioactive Waste Management, held at Seattle, Washington, May 16-20, 1983, IAEA-CN-43/446, Vol. 2, P. 239.

56. E. Passig, H. Hepp, Th. F. Kienle, and D. Rittscher, "Improvements in the Treatment, Voiume Reduction and Intermediate Storage of Radioactive Wastes from Nuclear Power Plants in the Federal Republic of Germany," Proceedings of the IAEA International Conference on Radioactive Waste Management, held at Seattle, Washington, May 16-20, 1983, IAEA-CN-143/445, Vo1. 2, p. 129.

57. H. Krause, "The Role of Wastes from Nuclear Power Plants in the Overall Management of Radioactive Wastes," Proceedings of an IAEA Seminar of the Management of Radioactive Waste from Nuclear Power Plants, held at Karisruhe, FRG, October 5-9, 1981, pp. 9-20, IAEA-TECDDC-276.

58. H. N. Sethna, R. Ramanna, V. N. Meckoni, and N. S. Sunder Rajan, "Waste Management Policy and Its Implementation in India," Proceedings of the IAEA International Conference on Radioactive Waste Management, held at Seatt1e, Washington, May 16-20, 1983, IAEA-CN-43/133, Vol. 1, p. 89.

59. N. S. Sunder Rajan, M. S. Kumra, M. K. S. Ray, M. T. Samuel, K. Raj, P. D. Ozarde, and V. N. Meckoni, "Treatment and Conditioning of Radioactive Wastes from Reprocessing Plants in India--A Review of the Status of the Projects," Proceedings of the IAEA International Conference on Radioactive Waste Management, held at Seattle, Washington, May 16-20, 1983, IAFA-CN-43/134, Vol. 2, p. 259.

60. K. Balu, A. L. Mohan, P. K. Narayan, V. B. Godse, and N. S. Sunder Rajan, "Twenty Years Experience with Shallow Ground Repositories in India," Proceedings of the IAEA International Conference on Radioactive waste Management, held at Seattle, Washington, May 16-20, 1983, IAEA-CN-43/135, vol. 3, p. 487 .

61. NUKEM Special Report, Italy, NUKEM GmbH, Hanau, FRG, July 1982.

62. A. Donato, "LLW and ILW Waste Management Practices in Italy," The Treatment and Handling of Radioactive Wastes, A. G. Blasewitz, J. M. Davis and M. R. Smith, eds., Battelle Press/Springer-Verlag, pp. 243-247, 1983.

63. G. Fukuda, K. Matsumoto, and K. Miyahara, "Experience and Projects for Treatment, Conditioning, and Storage of all Radioactive wastes from Tokai Reprocessing Plant," Proceedings of the IAEA International Conference on Radioactive Waste Management, held at Seattle, washington, May 16-20, 1983, Vol. 2, p. 279.

64. T. Ishihara, "The Japanese Approach to the Management of Radioactive Wastes," Proceedings of the CNS International Conference on Radioactive Waste Management, held at Winnipeg, Canada, September 1982, pp. 251-258, ISBN: 0-919784-01-1. 
65. M. Tsuchiya, "Low- and Intermediate-Level Waste Management Practices in Japan," The Treatment and Handling of Radioactive Wastes, A. G. Blasewitz, J. M. Davis and M. R. Smith, eds., Battelle Press/Springer-Verlag, pp. 252-255, 1983.

66. J. H. Lee, "Present Status of Radioactive Waste Management in Korea," Presented at the Third Korea/Japan Seminar on Atomic Industry, October 12-13, 1981 .

67. J. H. Lee and K. J. Chan, "Development of Incorporation of Evaporator Concentrate from Pressurized Water Nuclear Power Reactors into Asphalt," Proceedings of the OECD/IAEA Symposium of the 0n-Site Management of Power Reactor Wastes, held at Zurich, Switzerland, March 26-30, 1979, pp. $481-493$.

68. "RCN Opens Radioactive Waste Handling Facility," Nuclear Engineering International, June 1976, P. 42.

69. C. Konig, "Conditioning of Low-Level Solid Radioactive Wastes for Sea Disposal at ECN, Petten," IAEA Symposium, Vienna, 1983, IAEA-CN-261/25.

70. "Waste Repository," Nuclear Engineering International, 28(339):13, April 1983.

71. NUKEM Special Report, Spain, NUKEM GmbH, Hanau, FRG, April 1979.

72. B. Lopez Perez, L. Ramos Salvador, and A. Martinez Martinez, "Spanish National Radioactive Waste Management Program," Proceedings of the IAEA International Conference on Nuclear Power and It S Fuel Cycle, held at Salzburg, Austria, May 2-13, 1977, Vol. 4, pp. 437-445.

73. "Focus on Spain," NAC Update: A Monthly Review of the Nuclear Industry, Nuclear Assurance Corporation, Norcross, Georgia, Issue 17, April 1983.

74. R. Morcillo, E. Virzi, and M. Brownstein, "Retrofit of Radwaste Solidification Systems in Spain," Waste Management '83, Proceedings of the Symposium on Waste Management at Tucson, Arizona, February 27-March 3, 1983, pp. 367-373.

75. R. Sjöblom, "Low- and Intermediate-Level Waste Management in Sweden," Studsvik Technical Report $\mathrm{NW}-83 / 517$.

76. R. Sjöblom, et al., "Assessment of Properties of Swedish Reactor Waste," Proceedings of the IAEA International Conference on Radioactive waste Management, held at Seattle, Washington, May 16-20, 1983, IAEA-CN-43/132, Vol. 2, P. 159.

77. G. Rundquist, "Waste Management Policy and Its Implementation in Sweden," Proceedings of the IAEA International Conference on Radioactive Waste Management, held at Seattle, Washington, May 16-20, 1983, IAEA-CN-43/73, Vol. 1, p. 215. 
78. H. Fosstrom, S. Gustafsson, B. Persson, J. Ransmark, C. Thegerstrom, and G. Wickstrom, "Management of Radioactive Waste at Swedish Nuclear Power Plants," Proceedings of an IAEA Seminar on the Management of Radioactive Waste from Nuclear Power Plants, held at Karlsruhe, FRG, October 5-9, 1981, pp. 121-133.

79. L. Nilsson, "A Central Repository for Final Disposal of the Swedish Low and Intermediate Level Reactor Wastes," Waste Management '82, Proceedings of the Symposium on Waste Management, held at Tucson, Arizona, March 8-11, 1982, Vol. 1, pp. 69-80.

80. R. Rometsch and H. Issler, "Establishing Repositories for Radioactive Wastes in Switzerland," Proceedings of the IAEA International Conference on Radioactive Waste Management, held at Seattle, Washington, May 16-20, 1983, IAEA-CN-43/431, Vol. 3, p. 191.

81. U. Niederer, "waste Management Policy and Its Implementation in Switzerland," Proceedings of the IAEA International Conference on Radioactive Waste Management, held at Seattle, Washington, May 16-20, 1983, IAEA-CN-43/14, Vol. 1, p. 203.

82. R. Rometsch, "Nuclear Waste Management in Switzerland," IAEA Bulletin, 24(2), June 1982 .

83. Nucleonics Week, April 15, 1982.

84. Chao-Ming Tsai, Bruce Pao-Hsi Chu, and Pao-Shan Weng, "The Perspective of Radioactive Waste Management in the Republic of China," Proceedings unknown, C. 1976.

85. N. J. Keen and A. G. Duncan, "A Review of Radioactive Waste Management Programmes in the United Kingdom," The Treatment and Handling of Radioactive Wastes, A. G. Blasewitz, J.M. Davis and M. R. Smith, eds., Battelle Press/Springer-Verlag, pp. 34-39, 1983.

86. G. M. Wedd, "UK Radioactive Waste Management Policy and Strategy," Proceedings of the IAEA International Conference on Radioactive Waste Management, held at Seattle, Washington, May 16-20, 1983, IAEA-CN-43/20, Vol. 1, p. 125.

87. N. T. Mitchell and J. G. Shepherd, "The UK Disposal of Solid Radioactive Waste into the Atlantic Dcean and its Environmental Impact," Environmental Impact of Nuclear Power, BNES, London, 19B1, pp. 119-154.

88. Radioactive Waste Management, Command Number 8607, Her Majesty's Stationary Office, London, July 1982.

89. H. A. Taylor and J. W. Kennedy, "The Management of Radioactive Wastes Arising from Fuel Reprocessing Plants in the United Kingdom," Proceedings of the IAEA International Conference on Radioactive Waste Management, heid at Seattle, Washington, May 16-20, 1983, 1AEA-CN-43/22, Vol. 2, p. 249. 
90. A. H. Kibbey and H. W. Godbee, A State-of-the-Art Report on Low-Level Radioactive Waste Treatment, 1980 , ORNL/TM-7427.

91. D. E. Large et al., Proceedings of the Third Annual Information Meeting: DOE Low-Level Waste Management Program, ORNL/NRW-81/34, December 1981.

92. R. Anderson, T. Beck, L. Cooley, and M. McCampbe11, "A Preliminary Impact Assessment of Institutional Radioactive Waste Disposal, "Proceedings of the Health Physics Society Symposium on Low-Level Radioactive Waste Management, held at Williamsburg, Virginia, February 11-15, 1979, EPA 520/3-79-002, May 1979, pp. 151-158.

93. National Academy of Sciences, The Shallow Land Burial of Low-Level Radioactively Contaminated Solid Waste, Report of Panel on Land Burial, 1976.

94. W. F. Holcomb, "A History of Ocean Disposal of Packaged Low-Level Radioactive Waste," Nuclear Safety, 23(2):183-197, March-April 1982.

95. United States Energy Research and Development Administration, Alternatives for Managing Waste from Reactors and Post-Fission Operations in the LWR Fuel Cycle, May 1976, ERDA 76-43, Washington, D.C.

96. W. A. Brobst, "Transportation of Nuclear Fuel and Waste," Presented at Waste Management 1974 Symposium, Department of Nuclear Engineering, University of Arizona, Tucson, Arizona.

97. F. B. Conlon and G. L. Pettigrew, Summary of Federal Regulations for Packaging and Transportation of Radioactive Materials, BRH/DMRE 71-1, U.S. Department of Health Education and Welfare Public Health Service, Bureau of Radiological Heaith, Rockville, Maryland, 1971.

98. J. M. Jordan, Low-Level Radioactive Waste Management: An Update, National Conference of State Legislatures, 444 North Capitol Street, N.W., Suite 203, washington, DC 20001, October 1984. 


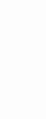


No. of

Copies

OFFSITE

DOE HEADQUARTERS

K. D. Ize11, $G-42$

office of the Generat Counsel

U. S. Department of Energy Forrestal

Washington, DC 20585

S. K. Kuznick, GC-3]

office of the ceneral

Counsel

U.S. Department of Energy

Forrestal

Washington, DC 20585

ง. A. Dugger, IE-121

U.S. Department of Energy

Forrestal

Washington, DC 20585

5. Griffith, IE-121

U.S. Department of Energy

Forrestal

Washington, DC 20585

H. Jaffe, IE-12

U.S. Departiment of Energy Forrestal

Washington, DC 20585

M. D. HCDonough, IE-122

U.S. Department of Energy Forrestal

Washington, DC 20585

T. K. Lau, IE-121

U.S. Departunent of Energy

Forrestal

Washington, DC 20585

W. Porter, IE-122

U.S. Department of Energy

Forrestal

Washington, DC 20585

K. W. Wentzel, IE-12

U.S. Department of Energy Forrestal

Washington, DC 20585

F. A. Minton, Jr., OP-432

U.S. Departinent of Energy Forrestal

Washington, DC 20585
No. of

Copies

R. L. Morgan, $Q P-2$

U.S. Departiment of Energy

Forrestal

Washington, DC 20585

R. D. Nelson, DP-431

U.S. Department of Energy

Forrestal

Washington, DC 20585

G. H. Daly, DP-10

U.S. Department of Energy GTN

Washington, OC 20545

T. C. Chase, $D P-123$

U.S. Department of Energy GTN

Washington, OC 20545

J. E. Dieckhoner, DP-122

U.S. Department of Energy GTN

Washington, DC 20545

R. K. Heusser, DP-132

U.S. Department of Energy GTN

Washington, DC 20545

J. J. Jicha, DP-123

U.S. Department of Energy GTI

Washington, DC 20545

D. B. LeClaire, $D P-12$

U.S. Department of Energy GTN

Washington, DC 20545

T. B. Hindman, $D P-12$

U.S. Department of Energy GTN

Washingtor, DC 20545

T. D. Arderson, $D P-121$

U.S. Departiment of Energy GTN

Washington, DC 20545

A. L. Taboas, $O P-12$ U.S. Department of Energy GTN

Washington, DC 20545
No. of

Copies

R. D. Walton, Jr, DP-123

U.S. Department of Energy GTN

Washington, OC 20545

L. R. Willett, DP-132

U.S. Department of Energy GTN

Washington, DC 20545

A. K. Walter, $I G-42$

L.S. Department of Energy Forrestal

Washington, DC 20585

5. Rosen, NE-75

U.S. Departinent of Energy GTN

Washington, DC 20545

J. E. Baublitz, NE-24

U.S. Oepartment of Energy GTN

Washington, DC 20545

R. B. Chitwood, NE-42

U.S. Departinent of Energy GTN

Washingtor, DC 20545

J. A. Coleman, NE-25

U.S. Department of Energy GTW

Washington, DC 20545

E. G. Delaney, NE-24

J.S. Departunent of Energy GTN

Washington, DC 20545

F. A. Goldner, NE -75

U.S. Department of Energy GTN

Washington, OC 20545

K. E. Horton, NE-75

U.S. Department of Energy GTN

Washington, DC 20545

D. 3. McGoff, NE-23

U.S. Department of Energy GTN

Washington, DC 20545 
No. of

Copies

H. H. Rohm, NE-50

U.S. Departinent of Energy

GTN

Washington, DC 20545

J. L. Smiley, NE-25

U.S. Department of Energy GTN

Washington, DC 20545

K. A. Xlein, RW-32

U.S. Departinent of Energy

Forrestal

Washington, DC 20585

C. R. Cooley, Rid-43

U.S. Department of Energy

Forrestal

Washington, DC 20585

J. J. Fiore, RW-22

U.S. Department of Energy

GTH

Washington, DC 20545

DOE OPERATIONS

W. O. Forster

Albuquerque Operations office

U.S. Department of Energy

P.0. Box 5400

Albuquerque, NM 87115

D. Campbel1

Albuquerque Operations Office

U.S. Department of Energy

P.0. Box 5400

A1buquerque, N 87115

M. H. MCF adden

Albuquerque operations office

U.S. Department of Energy

P.0. Box 5400

Aibuquerque, $N M$

J. M. McGough

Albuquerque Operations office

U.S. Department of Energy

P.0. Box 5400

Albuquerque, M 87115

H. 3. Rauch, Manager Chicago Operations office U.S. Department of Energy 9800 South Cass Avenue Argonne, IL 60439
No. of

Copies

S. A. Mann

Chicago Operations Office

U.S. Department of Energy

9800 South Cass Avenue

Argonne, IL 60439

J. 0. Neff

Salt Repository Project office

U.S. Department of Energy

505 King Avenue

Columbus, $\mathrm{OH} 43201$

H. J. Argyle

Idaho Operations office

U.S. Department of Energy

550 second Street

Idaho Falls, ID 83401

M. J. Barainca

Idaho Operations office

U.S. Departinent of Energy

550 Second Street

Idaho Falls, ID 83401

E. Maestas

West Valley Project office

U.S. Department of Energy

P.0. Box 191

West Valley, NY 14171-0191

T. E. Wade, II (Manager)

Idaho Operations office

U.S. Departiment of Energy

550 Second Street

Idaho Falls, to 83401

C. P. Gertz

Idaho Operations Office

U.S. Department of Energy

550 Second Street

Idaho Falls, ID 83401

R. D. Duncan

Nevada Operations office

U.S. Department of Energy

Las Vegas, NV 89114-4100

D. L. Vieth

Nevada Operations office

U.S. Department of Energy

Las Vegas, NV 89114-4100

S. Ahrends

Oak Ridge Operations office

U.S. Department of Energy

P.O. Box E

Oak Ridge, TN 37830
No. of

Copies

J. LaGrone, Manager

Oak Ridge Operations Office

U.S. Department of Energy

P.0. Box E

Oak Ridge, TN 37830

W. E. Pasko

Oak Ridge Operations

office

U.S. Department of Energy

P.0. Box E

Oak Ridge, TN 37830

L. Lanni

San Francisco Operations office

U.S. Department of Energy

1333 Broadway, Wells Fargo Building

Oakland, CA 94612

W. J. Brumley

Savannah River Operations Office

U.S. Departunent of Energy

P.O. Box A

Aiken, SC 29802

G. K. Oertel

Savannah River Operations office

U.S. Department of Energy

P.0. Box A

Aiken, SC 29802

J. T. D'Aunbrosia

Savannah River Operations office

U.S. Departinent of Energy

P.0. Box A

Aiken, SC 29801

W. H. Hannum

West Valley Project office

U.S. Department of Energy

P.0. Box 191

West Valley, NY 14171-0191

Technical Library

West Valley Project Office

U.S. Department of Energy

P.0. Box 191

West Valley, NY 14171-0191

30

DOE Technical Information Center 
No. of

Copies

\section{DOE CONTRACTORS}

\author{
S. S. Borys \\ Argonne National \\ Laboratory \\ 9700 South Cass Avenue \\ Argonne, IL 60439
}

M. J. Steindler, CMT-205

Argonne National

Laboratory

9700 South Cass Avenue

Argonne, IL 60439

S. M. Nealey

Battelle Menorial

Insti tute

Human Affairs Research Centers

4000 NE 41st Street

P.0. Box 5395

Seattle, WA 98105

C. R. Schuller

Battelle Memorial Institute

Human Affairs Research Centers

4000 NE 41 st Street

Seattle, WA 98105

Library

ATTN: Barbara Keen

Battelle Mennorial Insti tute

Human Affairs Research Centers

4000 NE 41 st Street

Seattle, WA 98105

L. A. Rancitelli

Battelle Memorial

Institute

505 Xing Avenue

Columbus, $\mathrm{OH} 43201$

B. Rawles

Office of Nuclear Waste Isolation

Battelle Memorial

Institute

505 King Avenue

Col unibus, $\mathrm{OH} 43201$

5 P. Col ambo, Bldg. 701

Brookhaven National

Laboratory

Upton, NY 11973
No, of

Copies

NWM Library

ATTN: S. G. Lane, B $1 \mathrm{dg} .830$

Brookhaven National Laboratory

Upton, NY 11973

G. R. Vineyard

Brookhaven Nationa!

Laboratory

Upton, NY 11973

E. A. Jennrich

EG\&G Idaho, Inc.

P.0. Box 1625

Idaho Falls, I0 83415

D. L. Uht, WCB E-2

EG\&G Idaho, Inc.

P.0. Box 1625

Idaho Falls, ID 83415

D. M. Kerr, Director

Los Al amos National

Laboratory

P.0. Box 1663

Los Alalnos, NM 87545

2 Report Library, MS-P364

Los Alarnos National

Laboratory

P.0. Box 1663

Los Alamos, M 87545

D. T. Dakley, MSF 671

Los Al amos Nationa?

Laboratory

P.0. Box 1663

Los Al anos, MM 87545

Technical Information

Department, $L-53$

Lawrence Livermore

National Laboratory

University of California

P.0. Box 808

Livermore, CA 94550

J. 0. B1omeke

Oak Ridge National

Laboratory

P.0. Box $X$

Oak Ridge, TN 37831

W. D. Burch

Oak Ridge Nationa?

Laboratory

P.0. Box X

Oak Ridge, TN 37831
No. of

Copies

H. W. Godbee

Oak Ridge National

Laboratory

P.0. Box X

Oak Ridge, TN 37331

L. J. Mezga

Bldg. $1505 / 106$

0ak Ridge Nationa 1

Laboratory

P.0. Box X

Oak Ridge, TN 37831

H. Postma

Oak Ridge National

Laboratory

P.0. Box X

Oak Ridge, TN 37831

T. H. Row

Bldg. 4500-N, C-36

Oak Ridge National

Laboratory

P.0. Box $X$

Oak Ridge, TN 37831

Central Research Library, Acquisitions Section, Room I-103, Bldg. $4500 \mathrm{~N}$ Oak Ridge National

Laboratory

P.0. Box $X$

Dak Ridge, TN 37831

G. W. Meyers, LA10

Rocketdyne Division

Rockwell International

6633 Canoga Ave.

Canoga Park, CA 91304

P. G. Hagan

Rocky Flats Plant

Rockwell International Corporation

P.0. Box 464

Golden, CO 80401

i. E. Spaeth

Science Applications, Inc.

2769 South Highl and

Las Vegas, NV 89109

D. R. Anderson, Dept. 6334

Sandia National

Laboratories

P.0. Box 5800

Albuquerque, NM 87185 
No. of

Copies

J. F. Ney, Dept. 6340

Sandia National

Laboratories

P.0. Box 5800

A1buquerque, NM 87185

Technical Library

Sandia National

Laboratories

P.O. Box 5800

Albuquerque, NM 87185

R. W. Lynch, Dept. 6300

Sandia National

Laboratories

P.0. Box 5800

Albuquerque, NM 87185

W. D. Weart, Dept. 6330

Sandia National

Laboratories

P.0. Box 5800

Albuquerque, NM 87185

E. L. Albenesius, Research Manager

Savannah River Laboratory

E. I. du Pont

Aiken, Sc 29808-0001

2 SRL Records Section

Savannah River Laboratory

E. I. du Pont

Aiken, SC 29808-0001

E. J. Hennelly, 773-41A

Savannah River Laboratory

E. I. du Pont

Aiken, SC 29808-0001

J. T. Lowe

Savannah River Laboratory

E. I. du Pont

Aiken, SC 29808-0001

R. Maher

E. I. du Pont

Savannah River Plant

Aiken, SC 29808-0001

0. L. Mc In tosh

E. I. du Pont

Savannah River Plant

Aiken, SC 29808-0001
No. of

Copies

J. H. Saling

Westinghouse Electric

Corp.

Waste Technology Services

Division

P.0. Box 286

Madison, PA 15663-0286

R. A. Brown

Westinghouse Idaho Nuclear

Co., Inc.

P. O. Box 4000

Idaho Falls, ID 83403

M. T. Johnson

Westinghouse Idaho Nuclear

Co., Inc.

P.0. Box 4000

Idaho Falls, ID 83403

B. R. Wheeler

Westinghouse Idaho Nuclear Co., Inc.

P.0. Box 4000

Idaho Falls, I0 83403

J. F. Strahl

Weston

2301 Research Boulevard

Rockville, MD 20850

J. L. Knabenschuh

West Valley Nuclear

Services Inc.

P.0. Box 191

West Valley, NY 14171-0191

OTHER AGENCIES

R. F. Willians

Electric Power Research Institute

P.O. Box 10412

3412 Hillview Avenue

Palo Alto, CA 94304

Library

GA Technologies Inc.

P.0. Box 85608

San Diego, CA 92138

B. J. Baxter

GA Technologies Inc.

P.0. Box 85608

10955 John Day Hopkins

Drive

San Diego, CA 92138
No. of

Copies

R. N. Orake

GA Technologies Inc.

P.0. Box 85608

10955 John Day Hopkins orive

San Diego, CA 92138

J. H. Hickman

Department of Health Services

Radiologic Health Branch

1232 Q Street

Sacramento, CA 95804

H. W. Paige

International Energy

Associates, Limited

2600 Virginia Ave., NW

Washington, DC 20037

J. A. McBride

E. R. Johnson Associates, Inc.

11702 Bownan Green Drive

Reston, VA 22090

FEDERAL AGENCIES

3. P. Colton

U.S. Arms Control and Disarmanent Agency

Washington, DC 20451

A. Sielen

Environnental Protection Agency

office of international

Activities

Washington, DC 20460

F. L. Galpin, MC ANR -460

Environilental Protection Agency

waste Management Standards Branch

Criteria and Standards Division

Washington, DC 20460

W. F. Hoicomb, MC ANR -460

Environmental Protection

Agency

office of Radiation

Prograns

401-M Street, S.W.

Washington, OC 20460 
No. of

Copies

S. Meyers, MC ANR-458

Environmental Protection Agency

Office of Radiation Programs

401-M Street, S.W.

Washington, OC 20460

P. Myers

National Academy of Sciences

Board on Radioactive Waste Management

RoOil $\mathrm{JH}-826$

2101 Constitution

Avenue, $N W^{\prime}$

Washington, DC 20418

O. M. Rohrer, MS-359-EW/W

U.S. Nuclear Regulatory Commission

office of Inspection and Enforcentent.

Washington, DC 20555

K. D. Burke, MS 406-EWS

U.S. Nuclear Regulatory Commission

Office of International prograns

Washington, DC 20555

M. R. Peterson, MS 414A-EWS

U.S. Nuclear Regulatory Commission

office of International Programs

Washington, DC 20555

K. R. Goller, MS 1130-SS

U.S. Nuclear Regulatory Commission

Office of Nuclear Regulatory Research

Division of Health, Siting, and Waste Management

Washington, oC 20555

R. E. Browning, MS 623-SS

U.S. Nuclear Regulatory Comnission

office of Nuclear

Materials Safety, and

Safeguards

Washington, DC 20555
No, of

Copies

E. F. Conti, MS 1130-55

U.S. Nuclear Regulatory Commission

Division of Radiation Prograns and Earth Sciences

Washington, DC 20555

Dr. Jose L. M. Cortez, MS 1130-5S

U.S. Nuclear Regulatory Commission

office of Nuclear Regulatory Research

Division of Health, Siting, and waste Managenent

Washington, DC 20555

K. S. Kim, MS 1130-SS

U.S. Nuclear Regulatory Commission

office of Nuclear Regulatory Research

Division of Health, Siting, and Waste Management

Washington, DC 20555

G. W. Roles

U.S. Nuclear Regulatory Cominission

Office of Low-Level Waste Management

Washington, DC 20555

Reference Library ATTN: M Conymgham, MS 160

U.S. Nuclear Regulatory Comtrission

Office of Nuclear Regulatory Research

Division of Health, siting, and waste Management Washington, DC 20555

G. A. Dinwiddie Hazardous Waste Hydrology Water Resources Division 410 National Center Reston, VA 22092
No. of

Copies

\section{FOREIGN}

C. Thegerströn

Svensk Kärnbränsl ehantering $A B$ (SKB)

Box 5864

S-102 48 Stockholin

Sweden

ONSITE

10 DOE Richland 0perations Office

T. A. Bauman

P. Brimhall

M. Dayant (2)

M. J. Lawrence

R. A. Hol ten

H. E. Ransom

J. L. Rhoades

G. Schmidtke

J. 0 . White

8 Rockwel1-Hanford

C. L. Brown

C. V. Di Pol

P. G. Lorenzini

S. J. Phillips

R. Prosser

J. H. Roecker

W. W. Schulz

J. K. Braden, Technical Information Center

2 UNC Nuclear Industries

W. 1. Kyriazis

R. A. Paasch

3 Westinghouse Hanford Corporation

E. A. Evans

R. D. Lerch

S. J, Mayhan

65

\section{Pacific Northwest Laboratory}

W. W. Ball ard

W. F. Bonner

J. B. Brown

J. L. Buelt

T. 0. Chikalla

J. M. Davidson 
No. of

Copies

Pacific Northwest Laboratory (contd)
R. M. Fleischman
G. W. Gee
M. J. Graham
K. M. Harmon (15)
J. N. Hartley
A. B. Johnson, Jr.
C. T. Kincaid
R. J. Kofoed
L. T. Lakey (15)

No. of

Copies

Pacific Northwest Laboratory (contd)

D. E. Larson

I. W. Leigh

R. C. Liikala

J. L. AkEl roy

R. B. McKee

J. E. Mendel

D. A. Myers

B. A. Napier

D. R. Oden
No. of

Copies

\section{Pacific Northwest Laboratory (contd)}
R. W. Perkins
A. M. Platt
J. V. Robinson
K. J. Schreider
J. A. Stottlemyre
N. A. Woyman
Publishing Coordination (2)
Technical Information (5) 